\title{
Was the Mangala Valles system incised by volcanic flows?
}

\author{
David W. Leverington ${ }^{1}$ \\ Received 18 January 2007; revised 31 May 2007; accepted 9 August 2007; published 20 November 2007.
}

[1] The Mangala Valles system of channels heads at one of the graben that comprise Memnonia Fossae, extends northward nearly $1000 \mathrm{~km}$ across Noachian and Hesperian highlands, and terminates at basins contiguous with Amazonis Planitia. The Mangala Valles system has previously been interpreted to have formed through one or more catastrophic aqueous floods on the basis of similarities between the characteristics of its channel landforms and those of terrestrial systems, including the Channeled Scabland of Washington. Although aqueous mechanisms for formation of Mangala Valles are broadly congruous with known characteristics of the channel system, an alternative volcanic hypothesis for formation of the system appears to be worthy of consideration on the basis of (1) its consistency with the volcanotectonic nature of the system and (2) commonalities between the basic nature of the system and that of large volcanic channels of the inner solar system. Estimates based on thermal considerations suggest that formation of Mangala Valles could conceivably have taken place through eruption of a lava volume of $\sim 2 \times 10^{5} \mathrm{~km}^{3}$, or roughly the total volume of the terrestrial Columbia River Basalt Group. The volcanic hypothesis for formation of Mangala Valles, and a hybrid hypothesis involving formation of Mangala Valles through aqueous processes followed by or in concert with substantial modification of the system by volcanic erosion and deposition, appears viable and worthy of future consideration.

Citation: Leverington, D. W. (2007), Was the Mangala Valles system incised by volcanic flows?, J. Geophys. Res., 112, E11005, doi:10.1029/2007JE002896.

\section{Introduction}

[2] The Mangala Valles outflow-channel system extends almost $1000 \mathrm{~km}$ across Noachian and Hesperian highlands of Memnonia, northward across the dichotomy boundary to Amazonis Planitia (Figures 1 and 2) [e.g., Milton, 1973; Baker and Milton, 1974; Carr, 1974b, 1981; Hartmann, 1974; Sharp and Malin, 1975; Mutch and Morris, 1979; Baker, 1982; Chapman et al., 1989; Tanaka and Chapman, 1990; Zimbelman et al., 1992; Chapman and Tanaka, 1993]. As with numerous other outflow channels on Mars, the Mangala Valles system is characterized by streamlined landforms and complexly anastamosing reaches [e.g., Milton, 1973; Chapman and Tanaka, 1993]. The channel system has a maximum width of $\sim 150 \mathrm{~km}$, and heads at a 5-km-wide breach in the northern flank of a single $\sim 1500$-km-long northeast-southwest trending graben. This feature (Figure 1: G) is part of Memnonia Fossae, which forms part of a large system of graben aligned radially to Arsia Mons and that is hypothesized to have formed through flexural loading, isostatic stresses, and/or dike emplacement [Carr, 1974a; Wise et al., 1979; Plescia and Saunders, 1982; McKenzie and Nimmo, 1999; Wilson and Head, 2002; Mège et al., 2003; Schultz et al., 2004].

\footnotetext{
${ }^{1}$ Department of Geosciences, Texas Tech University, Lubbock, Texas, USA.

Copyright 2007 by the American Geophysical Union. 0148-0227/07/2007JE002896\$09.00
}

Although the main Mangala Valles system heads at a graben, a hypothesized secondary source of fluids into the Mangala Valles system, identified on the basis of scour and subchannel features oriented radially to a prominent ridge (Figure 1: C and $\mathrm{R}$ ), is a thrust fault that intersects the source graben nearly at right angles, east of the head of Mangala Valles [Zimbelman et al., 1992].

[3] Partly on the basis of spatial variation in crater counts, the Mangala Valles system has been previously hypothesized to have formed through multiple flow events, some or all of which may have been correlated in time with lateHesperian or Hesperian-Amazonian episodes of volcanism and tectonism in the region [Tanaka and Chapman, 1990]. Regardless of the exact timing of the formation of Mangala Valles, the system is generally interpreted to have formed by catastrophic aqueous floods over a combined period of days to thousands of days [e.g., see Ghatan et al., 2005].

[4] Floods at Mangala Valles are hypothesized to have been driven by the hydraulic head associated with subsurface waters confined by ground ice or other low-permeability materials [e.g., Sharp and Malin, 1975; Tanaka and Chapman, 1990; Zimbelman et al., 1992; Head and Wilson, 2002; Ghatan et al., 2005]. One proposed scenario for formation of Mangala Valles involves the melting of a portion of a large near-surface body of ground ice in permafrost by increases in Tharsis-related heat flow or by upward displacement of the melting isotherm by the emplacement of lava flows over an original frozen surface [Zimbelman et al., 1992]. Another scenario involves fault- 


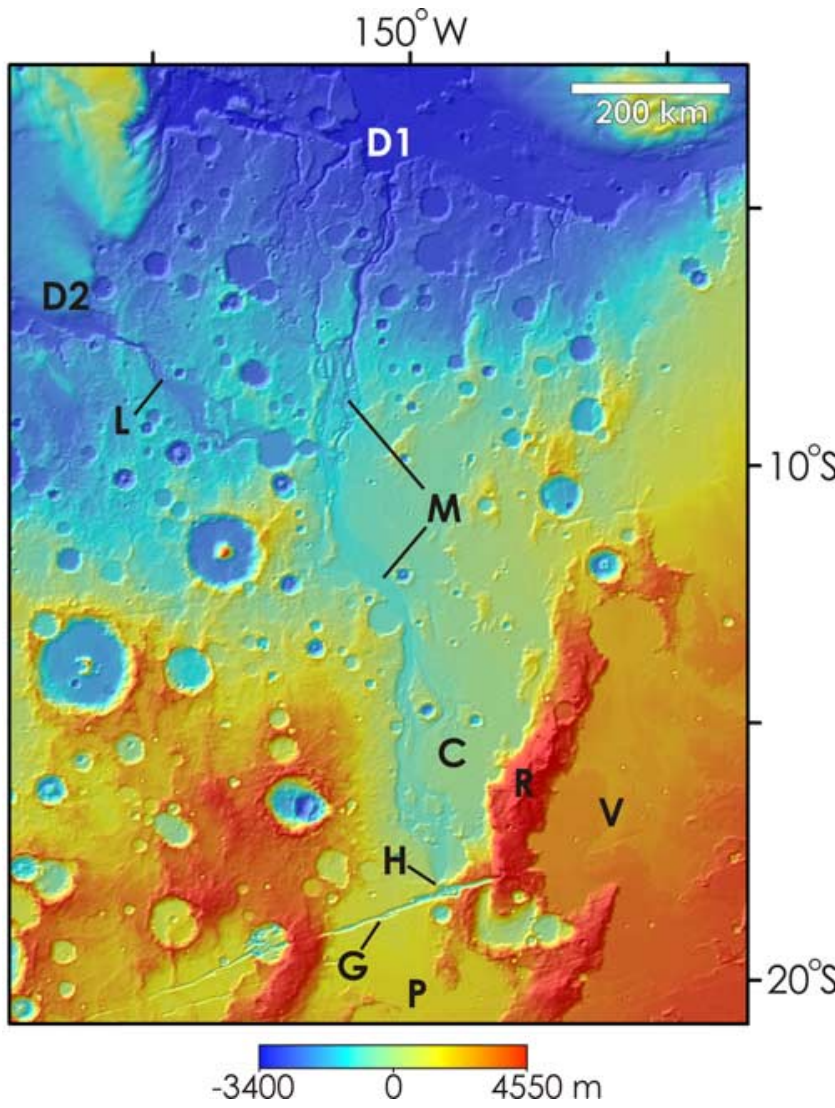

Figure 1. Mars Orbiter Laser Altimeter (MOLA) elevations for the Mangala Valles system. M, main branch of Mangala Valles; L, Labou Vallis branch; $\mathrm{H}$, head of Mangala Valles; G, source graben; P, plains south of source graben; V, plains at Daedalia Planum; $\mathrm{R}$, a large ridge of the circum-Tharsis ridge complex; $\mathrm{C}$, location of scours and subchannels oriented radially to the ridge, R; D1 and D2, dichotomy boundary at the channel mouths of Mangala Valles. A longitudinal profile along Mangala Valles, from $\mathrm{H}$ to D1, is given in Figure 2. Topographic model after Smith et al. [2003].

driven release at the head of Mangala Valles from aquifers pressurized under a confining cryosphere [Tanaka and Chapman, 1990; see also McCauley et al., 1972; Carr, 1979], with faulting possibly related to the emplacement of a Tharsis-radial dike swarm [Wilson and Head, 2002], and an estimated total water release of $\sim 2 \times 10^{13} \mathrm{~m}^{3}$ [Ghatan et al., 2005; see also, e.g., Baker and Milton, 1974; Komar, 1980; Baker, 1982; Zimbelman et al., 1992; Carr, 1996; Wilson et al., 2004]. A variation on this hypothesis involves localized tectonic pressurization of aquifers caused by formation of the source graben through catastrophic release of extensional crustal stress or through forceful injection of dikes at depth [Hanna and Phillips, 2006].

[5] Hypotheses previously proposed to account for the existence and characteristics of the Mangala Valles drainage system rely upon aqueous mechanisms of formation that involve the sudden release of large volumes of water from the subsurface through fractures associated with the source graben. These proposed mechanisms have substantial potential to account for the basic nature of the Mangala Valles system. However, it is noteworthy that there are no satisfactory analog processes, terrestrial or otherwise, for formation of large systems of incised channels by the catastrophic release of groundwater from fractures. Although proposed aqueous mechanisms for formation of Mangala Valles are congruous with known characteristics of the channel system, an alternative volcanic hypothesis for formation of the system appears worthy of consideration on the basis of its apparent consistency with landforms interpreted as volcanic at Mangala Valles and on other solar system bodies. Terrestrial, lunar, Venusian, and Martian landforms collectively suggest that nonaqueous volcanic processes may be sufficient to account for the existence and nature of the Mangala Valles system, without the need to invoke the action of past catastrophic aqueous flooding.

[6] This paper outlines a hypothesis for formation of the channels of the Mangala Valles system through nonaqueous volcanic processes. A summary of the geological setting of Mangala Valles is presented, followed by a review of the rationale behind previous aqueous interpretations of the channel system. An alternative volcanic hypothesis for formation of the channel system is outlined and discussed, and quantifications of basic aspects of this hypothesis are presented.

\section{Geological Setting of Mangala Valles}

[7] The graben at which the Mangala Valles system heads is discontinuously exposed at the surface and is oriented in a northeasterly direction, extending across Daedalia Planum at the most distal western flanks of Arsia Mons and the Tharsis rise [e.g., Tanaka and Chapman, 1990; see also, e.g., Carr, 1974a; Scott and Zimbelman, 1995; Mège et al., 2003]. At Daedalia Planum, the graben is partly covered by lava flows [e.g., Tanaka and Chapman, 1990], some units of which were erupted from the graben itself [Craddock and Greeley, 1994; see also Wilson and Head, 2002]. The graben is generally flat-floored and its morphology is

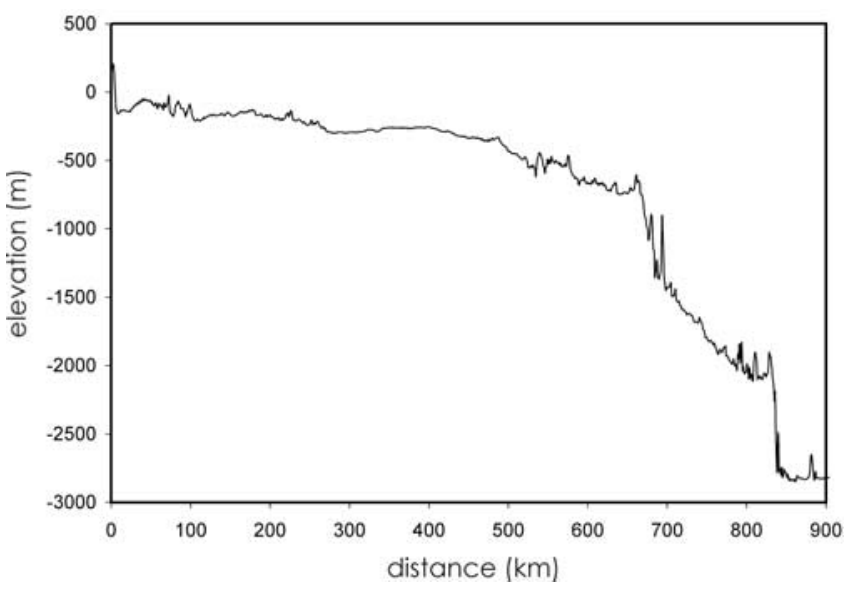

Figure 2. Longitudinal profile of Mangala Valles from $\mathrm{H}$ to D1 in Figure 1. Along-channel distance is expressed relative to the head of the system. Topographic model after Smith et al. [2003]. 

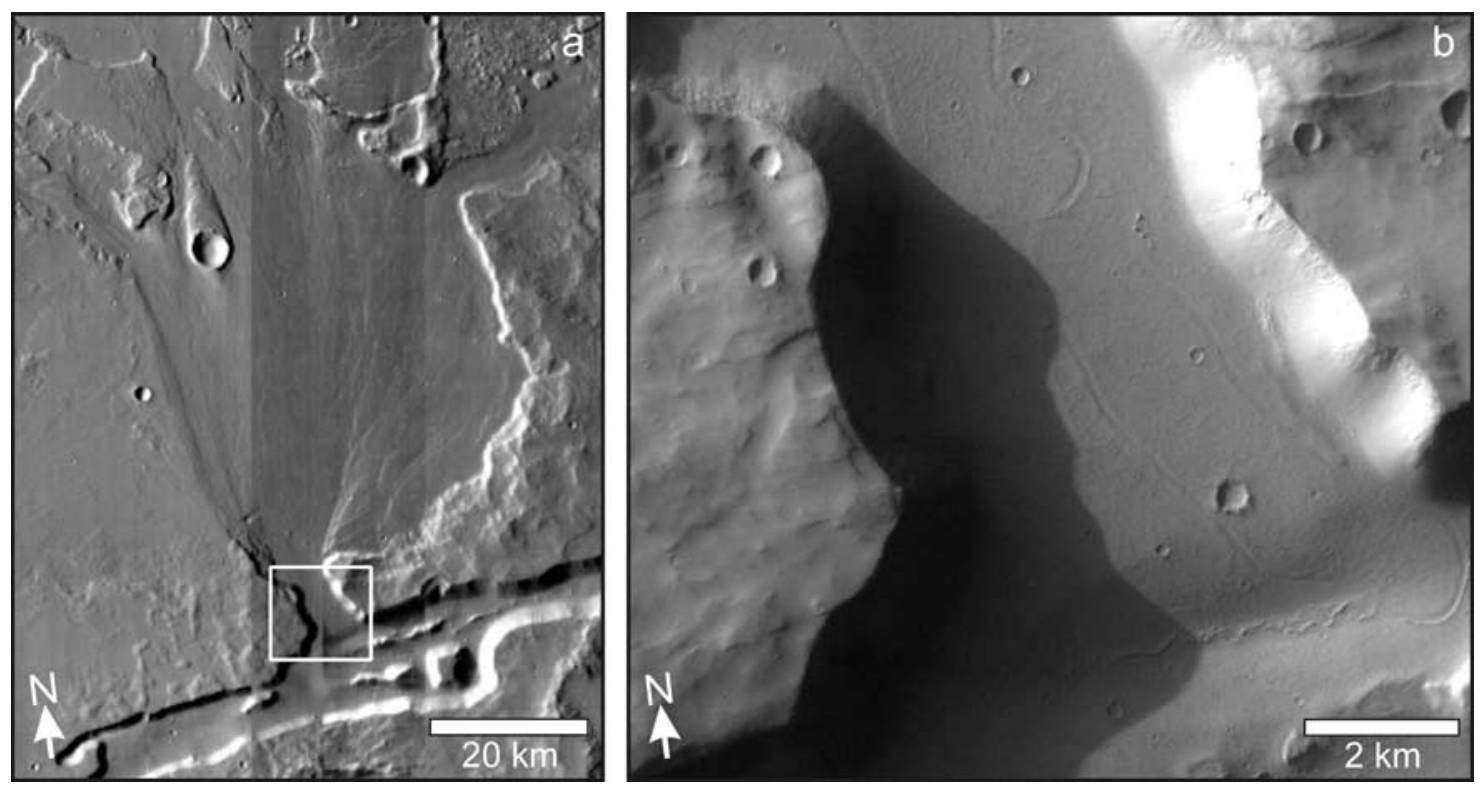

Figure 3. (a) Mosaic of THEMIS daytime thermal images of the head of Mangala Valles. Mosaic center $\sim 149^{\circ} 24^{\prime} \mathrm{W}, 17^{\circ} 40^{\prime} \mathrm{S}$. (b) THEMIS VIS image of the head of Mangala Valles (see also Figure 1: H). Band 3 of THEMIS image V04762003. Illumination in both frames is from the left.

suggestive of formation by two inward-dipping normal faults [e.g., Hanna and Phillips, 2006]. Although the main graben mainly has widths of $\sim 2 \mathrm{~km}$ and depths of tens to hundreds of meters, it is enlarged at the head of Mangala Valles to a trough with widths of $\sim 7 \mathrm{~km}$ and depths of up to $\sim 1.5 \mathrm{~km}$ [Ghatan et al., 2005]. A $\sim 5 \mathrm{~km}$ wide notch in the northern rim of this trough connects the graben to Mangala Valles (Figure 1: H; Figure 3) [see also Carr, 1981].

[8] Dune-like ridges located within tens of kilometers of the main source graben of Mangala Valles have been previously interpreted to have formed through explosive eruptions related to phreatomagmatic processes that preceded large outpourings of groundwater hypothesized to have formed the channels of Mangala Valles [Wilson and Head, 2004]. More prominent lobate-margined deposits located adjacent to the main source graben (Figure 4) have been previously interpreted to have formed by the outward flow of ice lobes formed by the freezing of water emitted from the graben [Head et al., 2004]. The span of the source graben at its intersection with a highland ridge to the east of the head of Mangala Valles (Figure 1: R; Figure 5a) is defined in part by numerous collapse pits considered suggestive of subsidence at a subgraben dike [Ghatan et al., 2005]. Extensive plains to the east of these collapse pits are interpreted to be composed of volcanic units that bury the source graben of Mangala Valles, and partly consist of flows erupted from the graben itself [e.g., Craddock and Greeley, 1994; see also Wilson and Head, 2002] (Figure 5b).

[9] Extensive smooth plains to the south of the graben (Figure 1: P) have been previously interpreted to have formed through aeolian or fluvial processes [Craddock and Greeley, 1994], although more recent research suggests that these plains are likely of volcanic origin, on the basis of the distribution of similar plains in the vicinity of circumTharsis ridges, their association with Tharsis volcanic flows, the manner in which older topography is embayed by the plains deposits, and the presence of features such as wrinkle ridges and apparent flow fronts [Ghatan et al., 2005]. Similar volcanic interpretations have been made for other ridged plains deposits located in the Mangala Valles region [e.g., Chapman and Tanaka, 1993], and a general regional association exists between volcanic plains and the Tharsisradial graben system [Wilson and Head, 2002]. The plains to the south of the head of Mangala Valles (Figure 1: P) are interpreted to have formed volcanically in conjunction with the volcanic resurfacing of Noachian terrain to the north, prior to the events that formed the channels of Mangala Valles [Ghatan et al., 2005].

[10] The channels of Mangala Valles are incised into the uplands of Memnonia, extending from the source graben northward to the dichotomy boundary. The primary channel network of Mangala Valles extends directly northward from the source graben, whereas a major branch of the system, Labou Vallis, reaches the dichotomy boundary by a northwestward path [e.g., Chapman and Tanaka, 1993] (Figure 1: $\mathrm{M}$ and $\mathrm{L}$ ). The downstream gradient of most of the Mangala Valles system is less than one degree, steepening only in the vicinity of the dichotomy boundary (Figure 2) [see also, e.g., Zimbelman et al., 1992, 1994; Ghatan et al., 2005]. Differences in crater-count ages within the Mangala Valles system have previously been used to suggest that multiple flow events formed its channels [Tanaka and Chapman, 1990], but it has been recently noted that measured channel gradients are not necessarily consistent with such age determinations [Ghatan et al., 2005]. It is also possible that differences in crater statistics between reaches of Mangala Valles instead reflect the sampling difficulties expected of regions of relatively small areal extent [Zimbelman et al., 1994].

[11] The Mangala Valles system is characterized by abundant streamlined landforms and anastamosing reaches [e.g., Milton, 1973; Baker and Milton, 1974; Baker, 1982; 


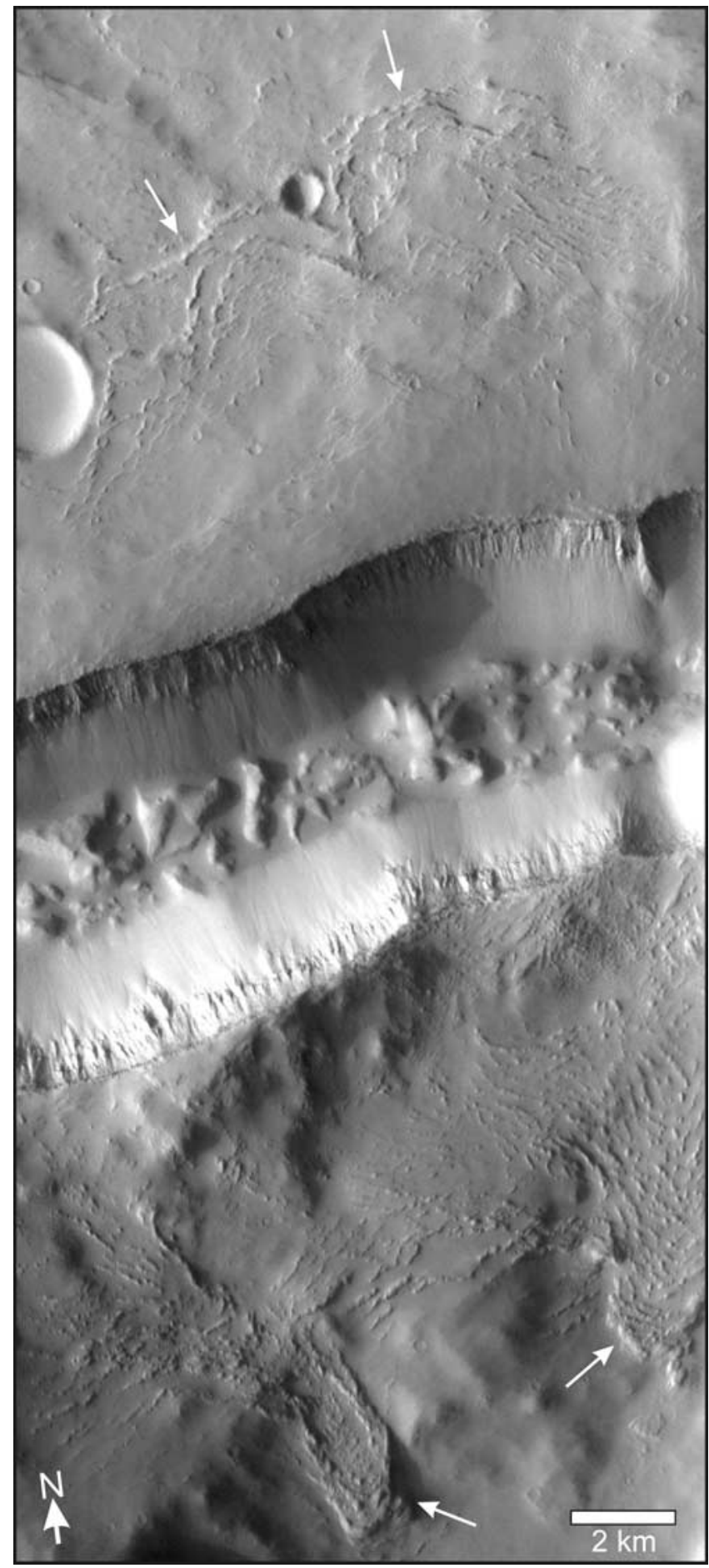

Figure 4. Lobate-margined deposits (see arrows for flow fronts) located adjacent to the main source graben of Mangala Valles and interpreted by Head et al. [2004] as having formed by freezing of water emitted from the graben [see also Levy and Head, 2005; Ghatan et al., 2005]. THEMIS VIS image; band 3 of image V06597003. Figure center at $\sim 148^{\circ} 37^{\prime} \mathrm{W}, 18^{\circ} 5^{\prime} \mathrm{S}$. Illumination is from the left.

Zimbelman et al., 1992, 1994; Chapman and Tanaka, 1993; Ghatan et al., 2005] (Figures 6 and 7). These streamlined landforms are aligned parallel to the flow paths of channels, except for landforms located $\sim 130 \mathrm{~km}$ downslope from the source graben that are oriented radially with respect to a possible volcanic rise located east of the channel system (Figure 1: C) [Zimbelman et al., 1992, 1994]. In contrast to earlier interpretations of streamlined landforms as having formed through the accumulation and erosion of alluvium [e.g., Chapman and Tanaka, 1993; Zimbelman et al., 1994], examination of more recently generated topographic and image databases suggests that most or all such landforms were generated through erosion of preexisting layered volcanic units [Ghatan et al., 2005]. The relations between streamlined and scoured landforms of Mangala Valles are complex, and the relative timing of formation of such landforms is in many cases unclear or even contradictory, particularly in the numerous cases of cross-cutting scour features [Ghatan et al., 2005; see also Zimbelman et al., 1994].

[12] Longitudinal grooves discontinuously extend along the floors of many channels of Mangala Valles (Figure 8) [see also Chapman and Tanaka, 1993], and have been previously interpreted at other Martian outflow channels as having formed through the action of catastrophic flooding or mud and debris flows [e.g., Baker and Milton, 1974; Thompson, 1979]; other hypothesized mechanisms have included aeolian processes [e.g., Sharp and Malin, 1975] or glacial processes [e.g., Lucchitta et al., 1981; Lucchitta, 2001]. Some landforms that appear at relatively coarse image resolutions as longitudinal grooves and ridges are recognizable at higher resolutions instead as dune fields and yardangs that in some cases deviate notably from channel paths (e.g., MOC image M0806100). Similar aeolian landforms are also found in upland regions surrounding parts of the Mangala Valles system (e.g., MOC images E1003072 and E1301768).

[13] Terraces are common along the margins of the channels of Mangala Valles [Chapman and Tanaka, 1993] (Figure 8), and in places several tens of stacked terraces are evident [Ghatan et al., 2005]; such terraces have been interpreted as having formed by erosion of layered volcanic units deposited prior to or during formation of the channel system, or having formed as fluvial depositional terraces during the waning stages of aqueous flooding [e.g., see Chapman and Tanaka, 1993; Ghatan et al., 2005]. Narrow leveed subchannels are present along some reaches of Mangala Valles, and a long $(100 \mathrm{~km})$ example has been interpreted as a rille that likely acted as a conduit for fluid volcanic flow (Figure 9) [Chapman and Tanaka, 1993].

[14] Plains units are discontinuously distributed through much of the channel system (Figure 10). While some plains materials have been interpreted as possible fluvial or lacustrine deposits [e.g., Chapman and Tanaka, 1993], many such materials have been interpreted as volcanic flows on the basis of their relatively high resistance to erosion and the presence of features such as lobate margins and wrinkle ridges [e.g., Zimbelman et al., 1992; Chapman and Tanaka, 1993; Ghatan et al., 2005]. Plains materials in and at the mouths of the channels of Mangala Valles are in places characterized by smooth surfaces pocked by quasi-circular pits, as well as lobate and cuspate margins [e.g., Zimbelman et al., 1992; Chapman and Tanaka, 1993; Ghatan et al., 2005; Levy and Head, 2005] (Figure 11); these materials have been interpreted as sublimation-lag deposits formed 

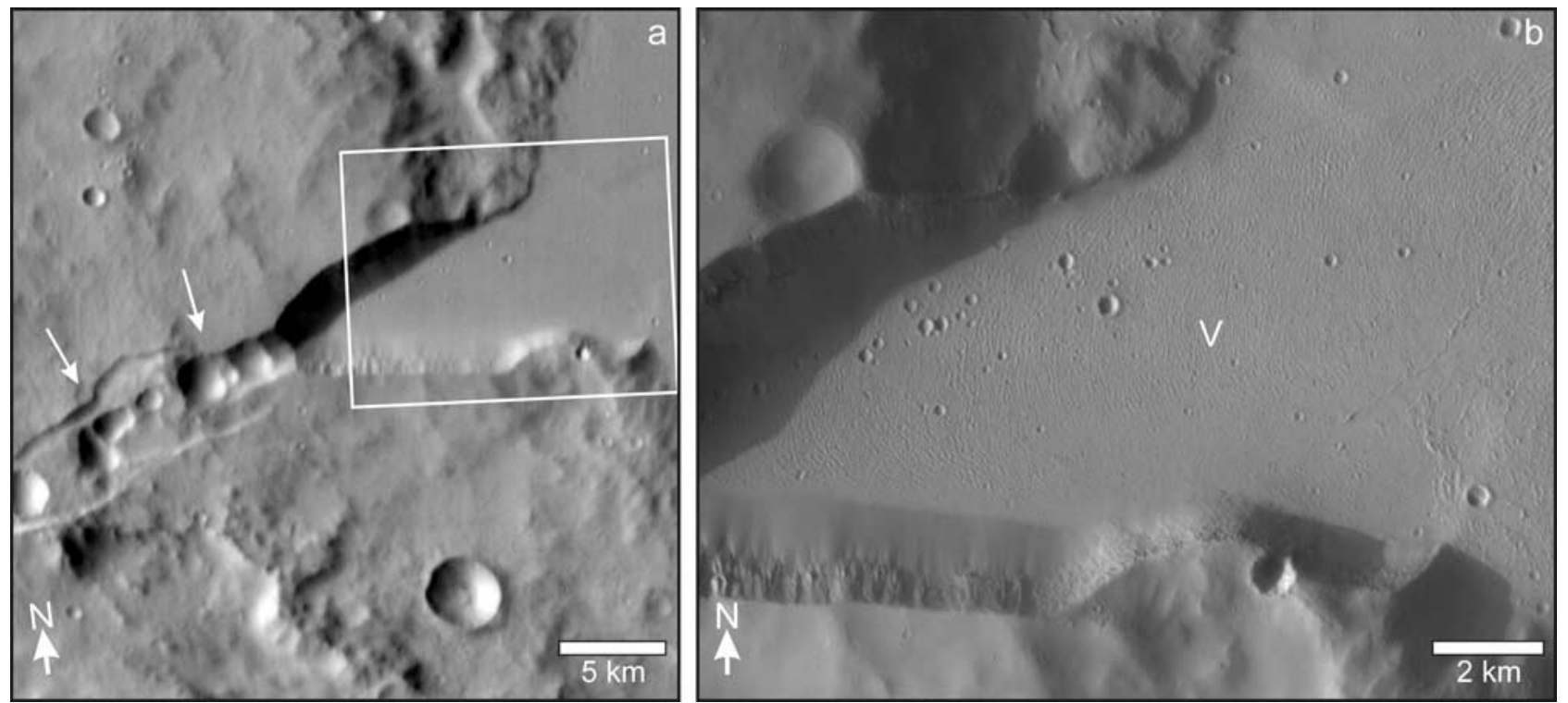

Figure 5. (a) Daytime thermal image of a segment of the source graben of Mangala Valles, east of $\mathrm{H}$ in Figure 1. Figure center is at $\sim 147^{\circ} 40^{\prime} \mathrm{W}, 17^{\circ} 50^{\prime} \mathrm{S}$. THEMIS image I01379001 (band 9). Collapse pits along a segment of the source graben are indicated by arrows [see also Ghatan et al., 2005]. (b) Plains units located east of the collapse pits, indicated by V, are interpreted as volcanic flood lavas, at least a proportion of which were erupted from the source graben of Mangala Valles [e.g., Craddock and Greeley, 1994]. Center of Figure $5 \mathrm{~b}$ is at $\sim 147^{\circ} 33^{\prime} \mathrm{W}, 17^{\circ} 51^{\prime} \mathrm{S}$. THEMIS VIS image; band 3 of image V06572003. Illumination in both frames is from the left.

from ice-rich flood deposits [Levy and Head, 2005; see also Zimbelman et al., 1992; Chapman and Tanaka, 1993]. Inverted channel topography evident along some reaches (Figure 12) has been interpreted as the product of emplacement of relatively resistant volcanic flows within these reaches, followed by differential erosion of channel materials [Chapman and Tanaka, 1993].

[15] Plains deposits, some of which have lobate margins or pitted surfaces, are present at the mouths of Mangala Valles channels at the dichotomy boundary. These deposits have been interpreted as possible mudflow deposits and icerich deposits, with more distal plains units interpreted as volcanic on the basis of the presence of wrinkle ridges and lobate margins [e.g., Chapman and Tanaka, 1993; see also Scott and Tanaka, 1986]. Deposits of the Medusae Fossae Formation extend across the terminal basins of Mangala Valles, and are interpreted as possible airfall deposits of volcanic origin [e.g., Bradley et al., 2002; Hynek et al., 2003; see also Chapman and Tanaka, 1993].

[16] Dune and megaripple fields (e.g., MOC images M0300429 and S0500890) overlay portions of Mangala Valles, with coverage greatest within several hundred kilometers of the dichotomy boundary. Much of the Mangala Valles system and surrounding region is mantled by other aeolian materials, as is indicated by the widespread presence of wind streaks, dark talus streaks, and dust-devil tracks.

\section{Evidence in Support of Aqueous Mechanisms of Channel Formation at Mangala Valles}

[17] Early studies of the outflow channels on Mars concluded that the channels were incised by large aqueous flows [e.g., Milton, 1973; Baker and Milton, 1974; Carr, 1974b; Sharp and Malin, 1975; Baker, 1978a; Baker and Kochel, 1978a, 1978b, 1979; Komar, 1980; Mars Channel Working Group, 1983], and subsequent studies of Mangala Valles have been conducted in acceptance (and further refinement) of these conclusions. The aqueous interpretation of Martian outflow channels is consistent with important attributes of Mars: the polar caps are known to be partly composed of water ice [e.g., Kieffer et al., 1976; Feldman et al., 2003; see also Smith et al., 1999], voluminous nearsurface reservoirs of water have been inferred for highlatitude regions using gamma-ray spectroscopy [Boynton et al., 2002; see also, e.g., Farmer and Doms, 1979; Clifford and Hillel, 1983], petrologic and chemical analyses of meteorites interpreted as Martian have revealed the presence of volatiles [e.g., Treiman, 1985; Karlsson et al., 1992], and Martian landforms exist with characteristics suggestive of formation by surface runoff or sapping [e.g., Milton, 1973; Masursky et al., 1977; Baker, 1982; Goldspiel et al., 1993; Mellon and Phillips, 2001; Moore et al., 2003; Hynek and Phillips, 2003; Howard et al., 2005]. However, the strongest evidence in support of the aqueous origins of Martian outflow channels, including the Mangala Valles system, relates to the similarity between the geomorphological characteristics of these channel systems and those of terrestrial systems known to have formed through processes related to aqueous floods.

[18] Most notably, the landforms of the Channeled Scabland of Washington, a drainage system formed by catastrophic release of water from ice-dammed glacial Lake Missoula [e.g., Bretz, 1928; Bretz et al., 1956; Baker, 1978b; Baker and Bunker, 1985; Smith, 1993], have been cited as sharing key characteristics with Martian outflow channels [Baker and Milton, 1974; Sharp and Malin, 1975; 


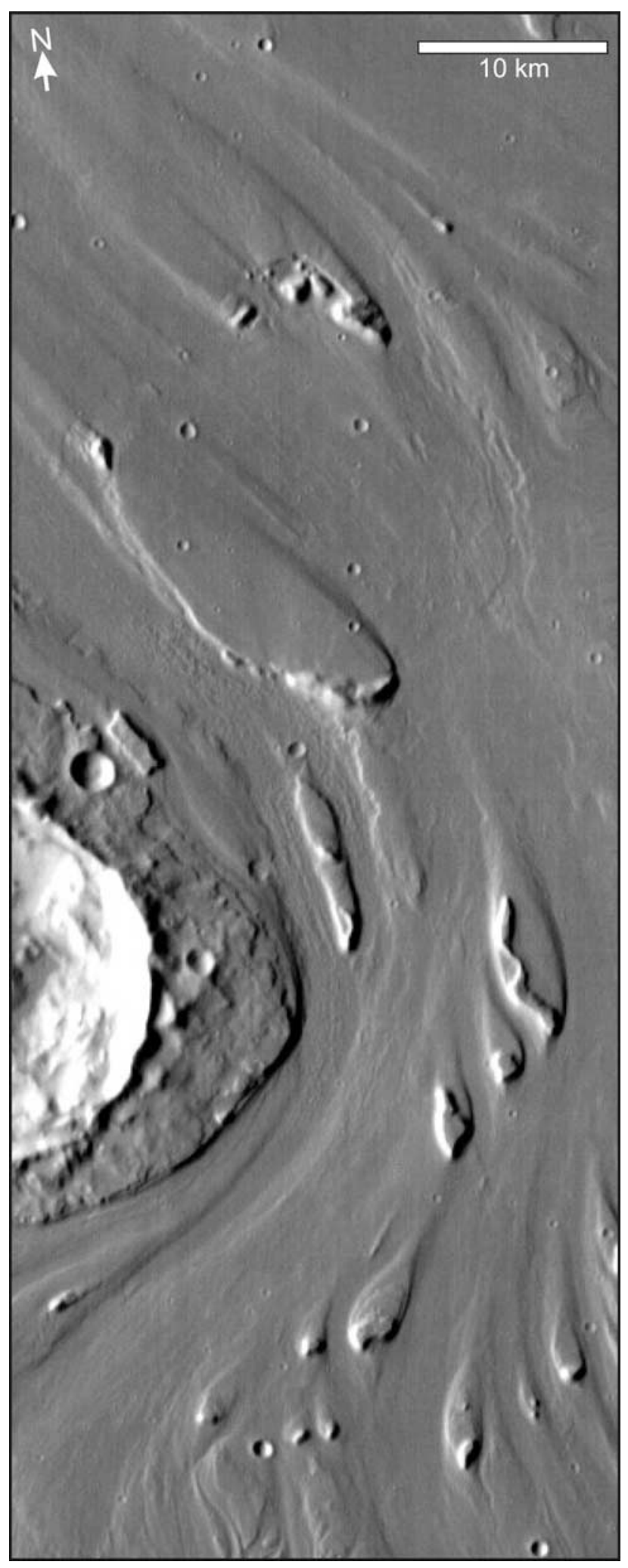

Figure 6. Daytime thermal image of streamlined landforms at Mangala Valles (THEMIS daytime infrared image I01429001, band 9). Figure center is at $\sim 149^{\circ} 19^{\prime} \mathrm{W}$, $14^{\circ} 35^{\prime} \mathrm{S}$. Illumination is from the left.

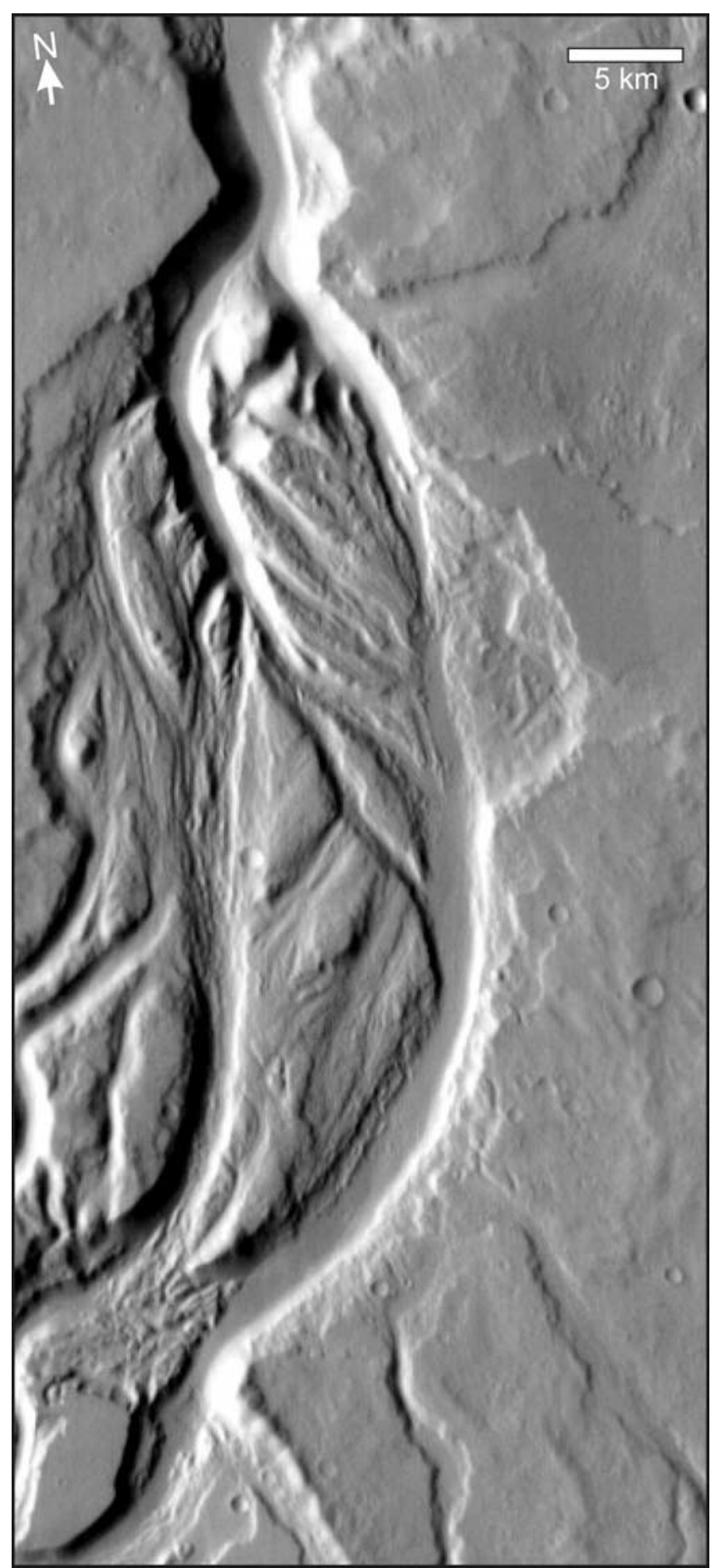

Figure 7. Daytime thermal image of complexly anastamosing reach of Mangala Valles (THEMIS daytime infrared image I01841001, band 9). The channel plains at image top are contiguous with and form part of the extensive plains of Amazonis Planitia [see also Baker and Milton, 1974; Sharp and Malin, 1975; Baker, 1982]. Figure center is at $\sim 150^{\circ} 22^{\prime} \mathrm{W}, 5^{\circ} 25^{\prime} \mathrm{S}$. Illumination is from the left. 


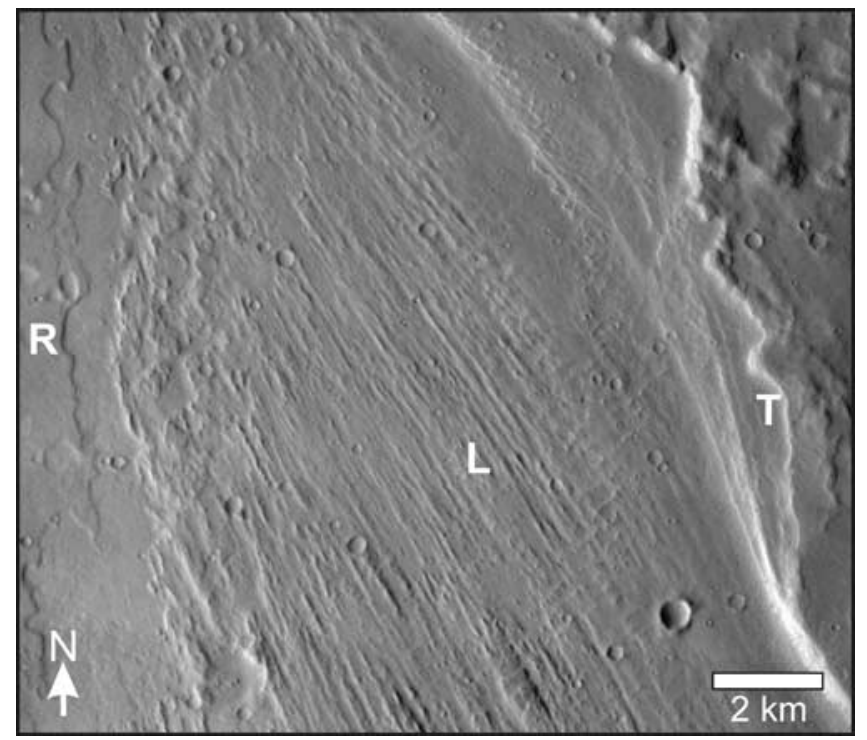

Figure 8. Channel terraces (T), longitudinal grooves (L), and smooth channel layers characterized by cuspate and arcuate margins (R). Flow in this area was toward the northwest. Channel plains such as those at $\mathrm{R}$ are interpreted by Levy and Head [2005] as remnant ice from aqueous floods that carved Mangala Valles. THEMIS VIS image; band 3 of image V06647001. Figure center is at $\sim 149^{\circ} 54^{\prime} \mathrm{W}, 13^{\circ} 15^{\prime} \mathrm{S}$. Illumination is from the left.

Baker, 1978c]. The conduits of both the Channeled Scabland and the Martian outflow channels are understood to form networks of true channels, rather than networks of valleys [Bretz, 1923, 1928; Milton, 1973; Baker and Milton, 1974]. Additionally, the shared characteristics of these channel systems include the anastamosing nature and variable widths of channels, the relatively high width-to-depth ratios and low sinuosity of channels, the presence of longitudinal grooves on channel floors and scour marks around obstacles, the presence of inner channels with recessional headcuts, and the presence of either depositional or erosional streamlined forms on the down-current sides of flow obstacles [Baker and Milton, 1974; Carr, 1974b; Sharp and Malin, 1975; Baker, 1978a, 1978b, 1978c, 1982; Baker and Kochel, 1978a, 1978b; Mars Channel Working Group, 1983].

[19] The Mangala Valles system itself shares a number of key geomorphological characteristics with the Channeled Scabland [e.g., Milton, 1973; Baker and Milton, 1974; Sharp and Malin, 1975; Baker, 1982]. Large quadrilateral residual forms, such as those that characterize the ChenyPalouse tract of the Channeled Scabland [Bretz, 1923; Bretz et al., 1956; Baker, 1978b], are also found in many of the channels of the Mangala Valles system (e.g., Figure 7) [Milton, 1973; Carr, 1974b; Sharp and Malin, 1975; Chapman and Tanaka, 1993]. The Channeled Scabland residuals have lengths as great as tens of kilometers and are mainly composed of basalt and loess deposits [e.g., Bretz, 1923; Baker, 1978b]. The Mangala Valles residuals similarly have lengths as great as tens of kilometers, and also may be composed of layered basalt units [Ghatan et al., 2005]. The large quadrilateral streamlined landforms may in both systems be erosional in origin [e.g., Baker, 1978b; Ghatan et al., 2005], although some such landforms at
Mangala Valles have previously been classified as possible depositional alluvial landforms [e.g., Baker, 1982; Chapman and Tanaka, 1993; Craddock and Greeley, 1994]. The complex anastamosing nature of the scabland channels is mirrored by the channels of Mangala Valles, with conduits in both systems defining the streamlined erosional residuals through bifurcation and convergence around them [e.g., Milton, 1973; Carr, 1974b; Sharp and Malin, 1975; Baker, 1978b; Chapman and Tanaka, 1993].

[20] At the Channeled Scabland, there are numerous subfluvially formed erosional transverse ledges that interrupt the floors of deeply incised inner channels and that acted as recessional cataracts to paleoflow [Bretz, 1928].

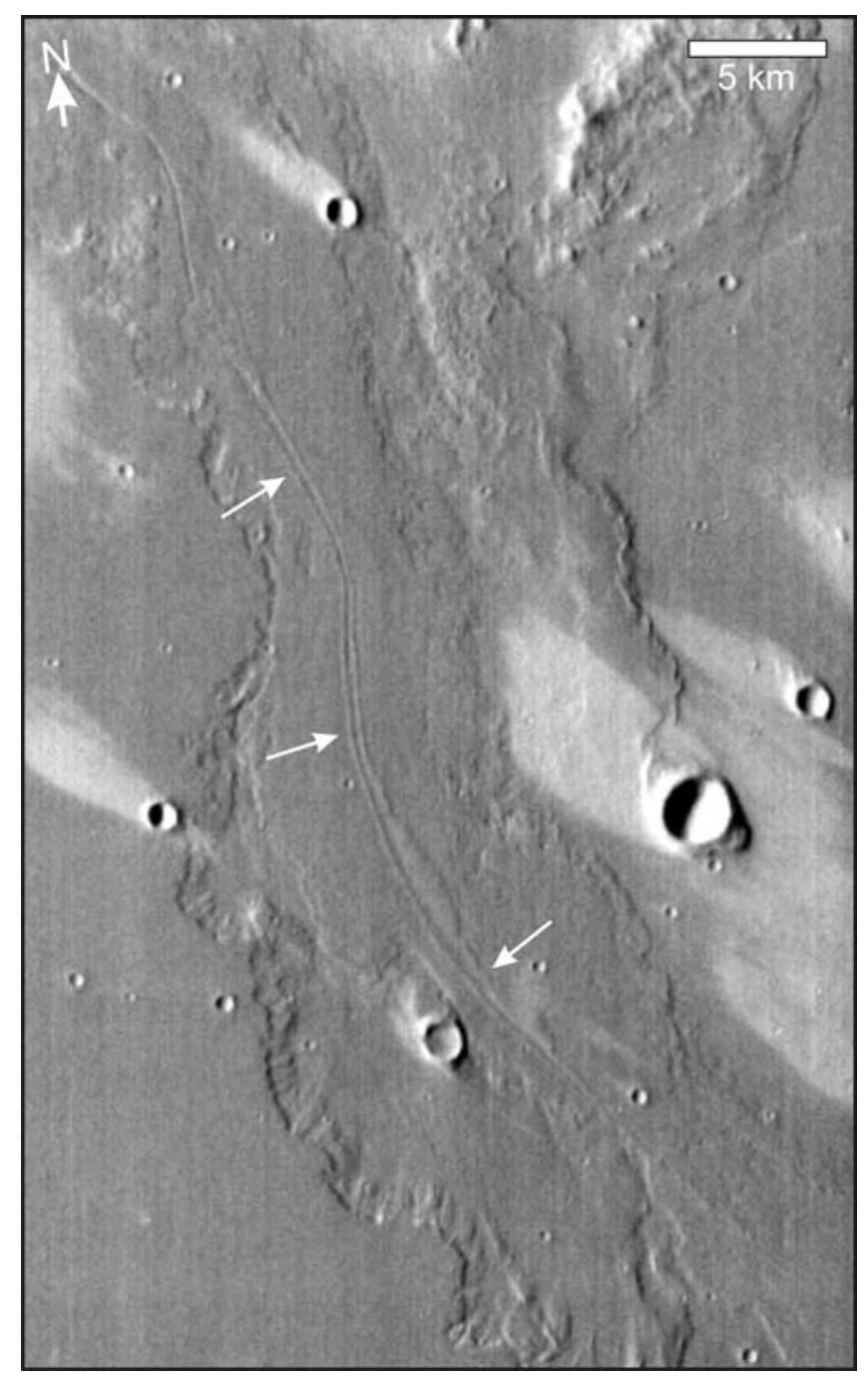

Figure 9. Segment of a $\sim 100-\mathrm{km}$-long leveed subchannel of Mangala Valles (see also THEMIS VIS image V06672001). This narrow channel is interpreted as a rille that likely acted as a conduit for fluid volcanic flow [Chapman and Tanaka, 1993]. Similar channels are found to the east on the distal flanks of Arsia Mons (e.g., THEMIS VIS image V15820002), at the graben at which Mangala Valles heads. Terrestrial volcanic channels of similar morphology have been recognized [e.g., Carr and Greeley, 1980, p. 123]. THEMIS daytime infrared image I10378012 (band 9). Figure center is at $\sim 150^{\circ} 40^{\prime} \mathrm{W}, 10^{\circ} 52^{\prime} \mathrm{S}$. Illumination is from the left. 

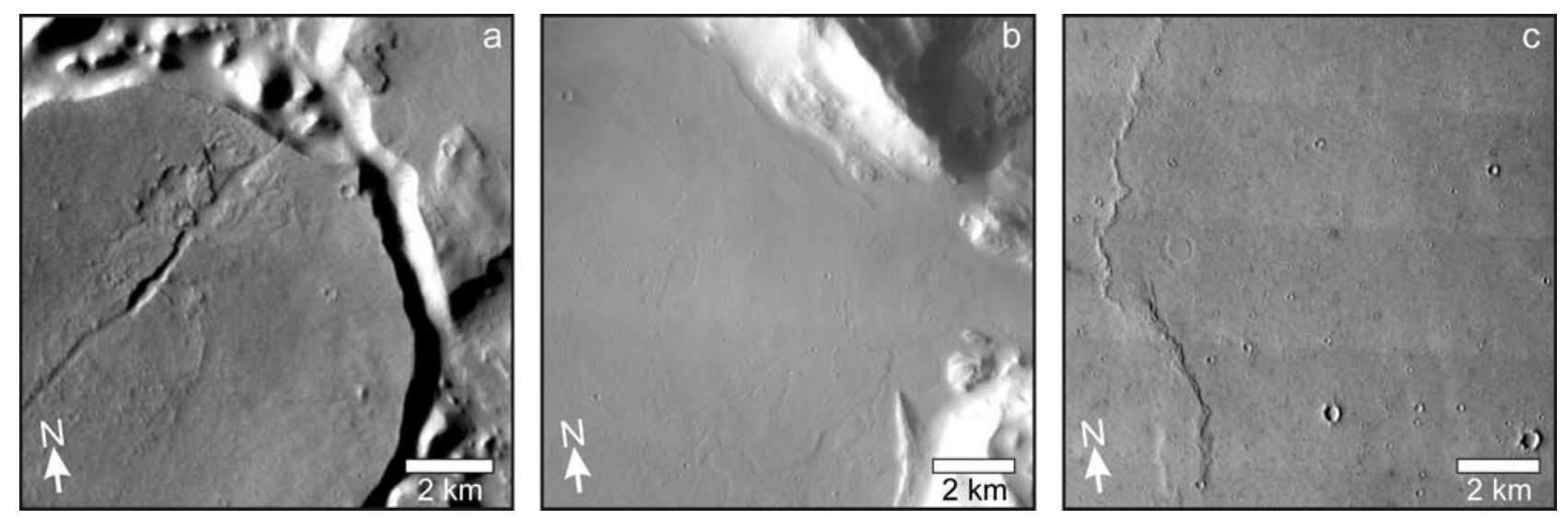

Figure 10. Examples of Mangala Valles plains units interpreted as lava flows on the basis of characteristics such as lobate unit margins, embayment of adjacent landforms, and the presence of wrinkle ridges [e.g., see Chapman and Tanaka, 1993; Ghatan et al., 2005]. THEMIS VIS images: (a) V10741002, band 3, figure center at $\sim 152^{\circ} 16^{\prime} \mathrm{W}, 7^{\circ} 5^{\prime} \mathrm{S}$; (b) V05973001, band 3, figure center at $\sim 151^{\circ} 54^{\prime} \mathrm{W}, 9^{\circ} 39^{\prime} \mathrm{S}$; and (c) V06235002, band 3, figure center at $\sim 148^{\circ} 10^{\prime} \mathrm{W}, 14^{\circ} 23^{\prime} \mathrm{S}$. Illumination in all frames is from the left.

These ledges may be generally described as horseshoeshaped headcuts with scour-formed closed depressions at the bases of each cataract alcove [Baker, 1978b]. The Dry Falls cataract, one of the largest such features in the Channeled Scabland, is $\sim 5.5 \mathrm{~km}$ across and $120 \mathrm{~m}$ high [e.g., Bretz, 1923; Baker, 1978b]. Although confident identification of this class of landform at Mangala Valles is difficult, inner channels that head at scarps oriented transversely to directions of past channel flow are relatively common features along much of the system's length (Figure 13) [see also Baker and Milton, 1974].

[21] Pre-flood tributaries to channels deeply excavated from earlier stream valleys in the Channeled Scabland form hanging valleys with floors up to hundreds of meters above the floors of excavated channels [e.g., Baker, 1978b]. At Mangala Valles, there are numerous examples of tributary channels stranded above more deeply incised channels (e.g., THEMIS VIS image V10429001). Some of the most prominent such examples include subchannel segments that terminate abruptly at the peripheries of large residual landforms within the main channel system itself (e.g., Figure 7).

[22] At the Channeled Scabland, distinctive scour depressions are found along the floors of numerous conduits, and appear to have formed by the action of vortices around and in the lee of bedrock projections and large boulders [e.g., Baker, 1978a, 1978b]. Channeled Scabland scour features and associated protuberances together define a characteristic butte-and-basin topography, with a total relief of about 30$100 \mathrm{~m}$; the dimensions of scours are as great as kilometers in length and tens of meters in depth [Baker, 1978b]. The pitted surfaces of some channel units of Mangala Valles have been identified as having possibly formed through scour by floodwaters [Sharp and Malin, 1975; Zimbelman et al., 1992], and some areas of irregular topography at Mangala Valles are candidate examples of butte-and-basin topography [Baker and Milton, 1974].

[23] Erosional longitudinal grooves in the Channeled Scabland, formed where individual basalt surfaces were eroded by flood flows, are typically separated horizontally by hundreds of meters, and average $5 \mathrm{~m}$ in depth and $50 \mathrm{~m}$

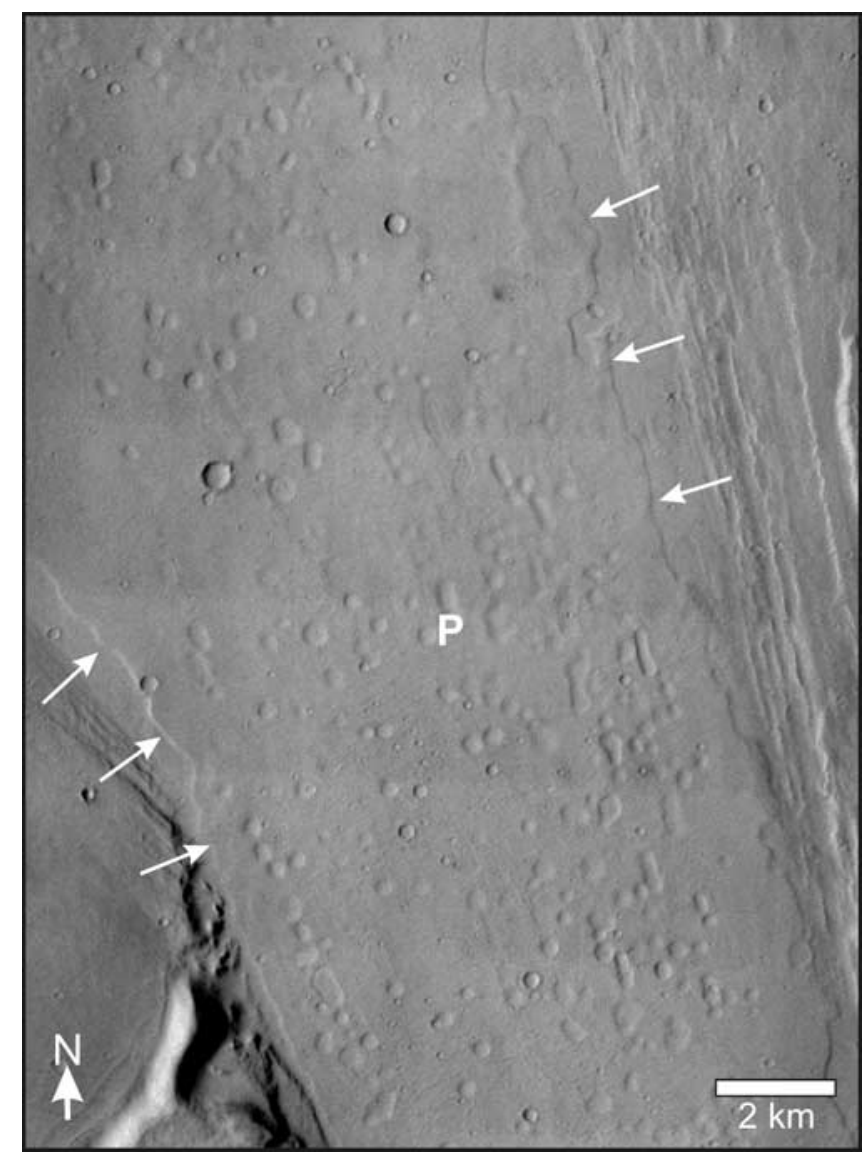

Figure 11. Smooth channel deposit with lobate margins (arrows) and quasi-circular pits (P). Such units have been previously interpreted as possible sublimation lag deposits formed from ice-rich units deposited during the aqueous flood proposed to have formed Mangala Valles [Levy and Head, 2005; see also Zimbelman et al., 1992; Chapman and Tanaka, 1993; Ghatan et al., 2005]. THEMIS VIS image V01454001 (band 3). Figure center is at $\sim 150^{\circ} 05^{\prime} \mathrm{W}$, $13^{\circ} 0^{\prime} \mathrm{S}$. Illumination is from the left. 


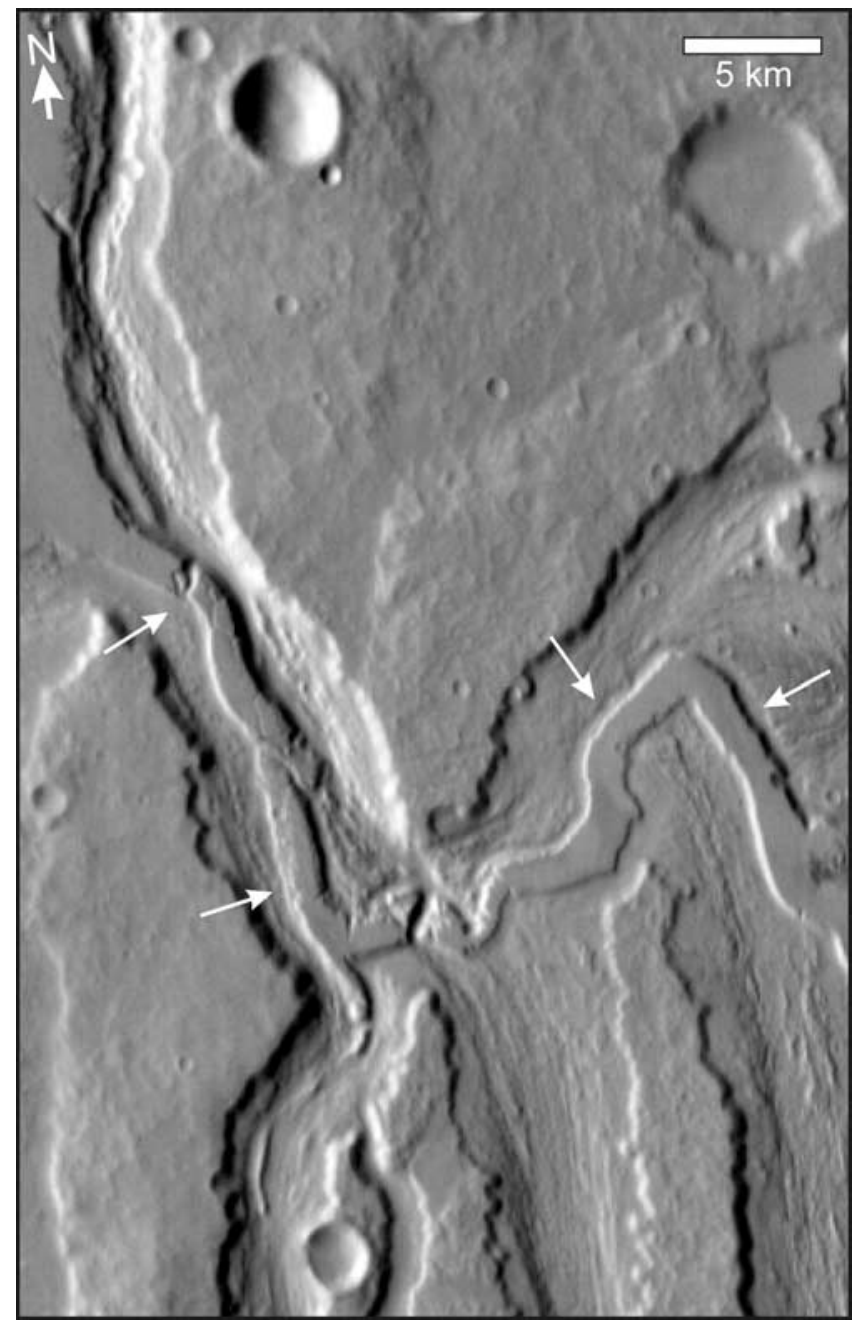

Figure 12. Mangala Valles inner channel (arrows) characterized by inverted topography due to differential erosion [e.g., Chapman and Tanaka, 1993]. THEMIS daytime infrared image I01866001 (band 9). Figure center is at $\sim 151^{\circ} 42^{\prime} \mathrm{W}, 7^{\circ} 48^{\prime} \mathrm{S}$. Illumination is from the left.

in width [Baker, 1978a, 1978b; Patton and Baker, 1978]. In the Cheney-Palouse region, the widest longitudinal groove is slightly under $300 \mathrm{~m}$ wide, and the deepest grooves have depths as great as $25 \mathrm{~m}$ [Patton and Baker, 1978]. Parallel gullies and ridges are common along the channel floors of Mangala Valles, defining lineations with lengths as great as ten or more kilometers and typical widths of $\sim 50$ to $300 \mathrm{~m}$ (Figure 8) [e.g., Tanaka and Chapman, 1990; Zimbelman et al., 1992; Chapman and Tanaka, 1993; Ghatan et al., 2005].

[24] Depositional landforms at the Channeled Scabland include longitudinal bars, eddy bars, and giant current ripples. Longitudinal bars, depositional features with long dimensions oriented parallel to flow direction and thicknesses of tens of meters, are found in relatively uniform Channeled Scabland reaches that lack abrupt changes in width [e.g., Bretz et al., 1956; Baker, 1978b]. Such bars, which include pendant bars, are present in the Channeled Scabland downstream from bedrock projections and other flow obstacles. Scabland eddy bars, poorly sorted sediment accumulations tens of meters thick and deposited in former environments of high turbulence, block the mouths of drainages entering the Cheny-Palouse scabland tract, and are associated with slackwater deposits that extend further up the tributary valleys [e.g., Bretz, 1925, 1928; Baker, 1978b; Benito and O'Connor, 2003]. Giant current ripples, composed of parallel ridges and swales with relief of up to $\sim 15 \mathrm{~m}$, are distributed in a number of scabland channels [Bretz et al., 1956; Baker, 1973, 1978b].

[25] At Mangala Valles, identification of landforms clearly formed through aggradation involving fluvial or diluvial processes has not yet been made, although there are many examples of channel features at the lee of obstacles to flow, and that conceivably could be depositional landforms (Figure 6) [see also, e.g., Milton, 1973; Tanaka and Chapman, 1990; Zimbelman et al., 1992; Ghatan et al., 2005]. Confident discrimination between erosional and depositional landforms in these cases has been problematic [e.g., Baker and Kochel, 1978a], and recent work suggests that most or all of the streamlined forms at Mangala Valles are erosional [Ghatan et al., 2005]; Burr [2005] has identified candidate depositional landforms associated with Athabasca Valles, a Martian channel system that heads at

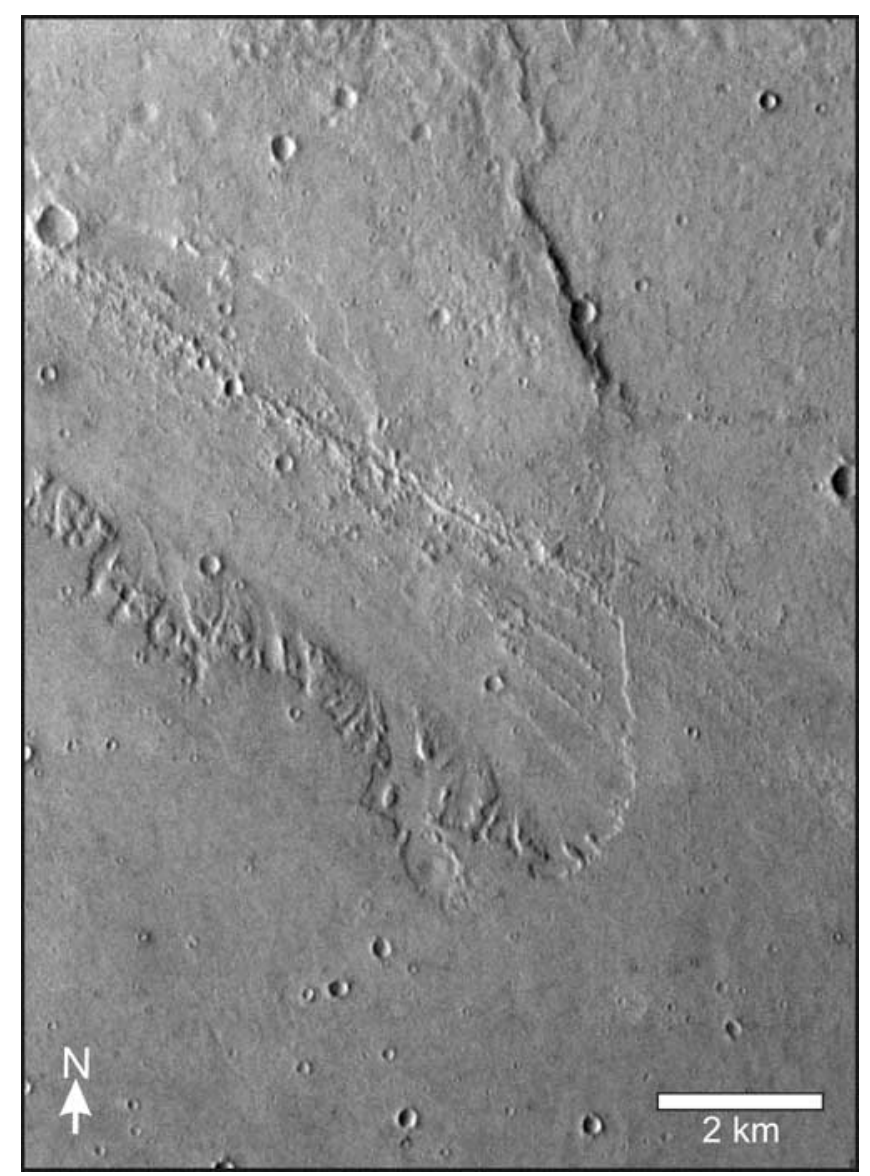

Figure 13. Mangala Valles subchannel that heads at a ledge oriented transversely to paleoflow. It is conceivable that the examples of this class of feature formed as recessional cataracts to paleoflow. Flow along this reach was from bottom right to top left. Band 3 of THEMIS VIS image V14622002. Figure center is at $\sim 148^{\circ} 12^{\prime} \mathrm{W}, 13^{\circ} 45^{\prime} \mathrm{S}$. Illumination is from the left. 


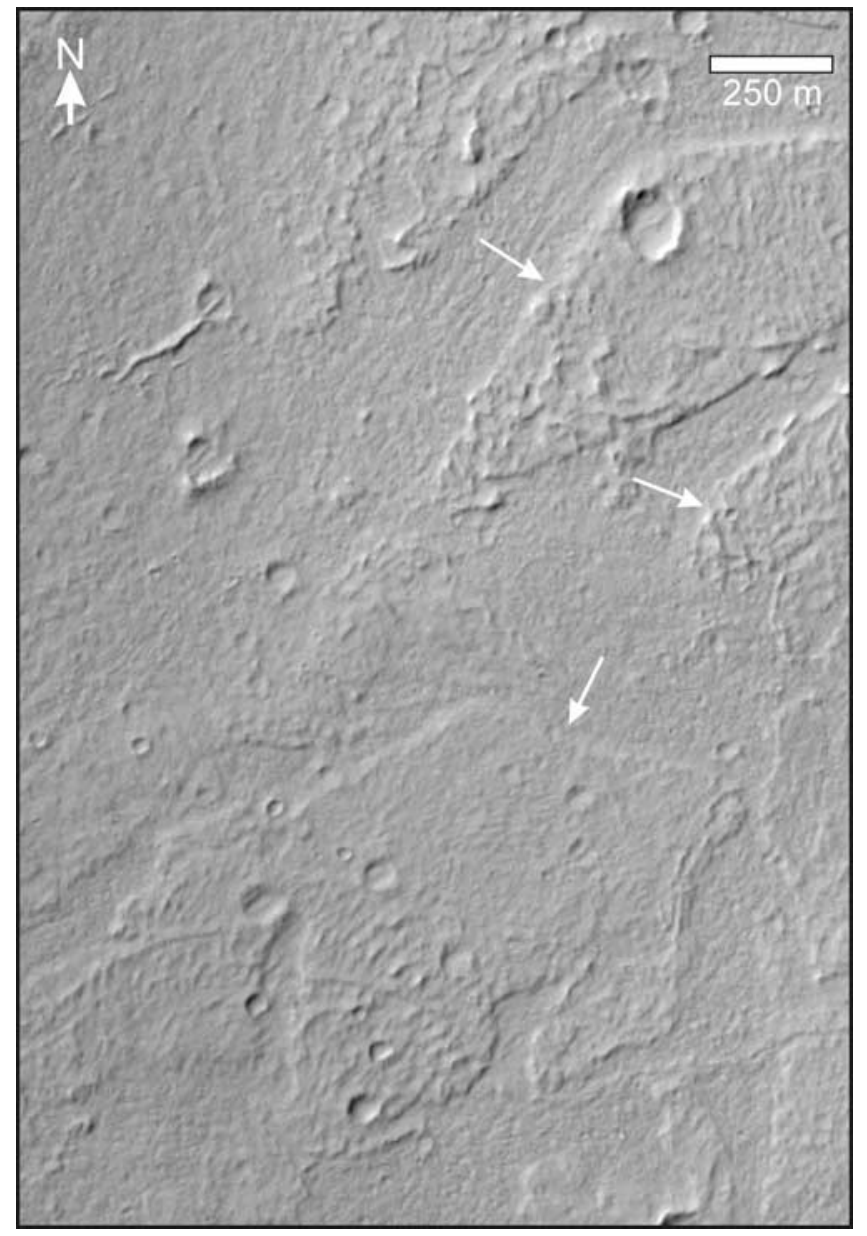

Figure 14. Fill materials with platy surfaces at Mangala Valles. Selected individual plates are indicated by arrows. Mars Orbiter Camera (MOC) image R1902042 (see also MOC images R0100876 and R1902042). Figure center is at $\sim 152^{\circ} 50^{\prime} \mathrm{W}, 9^{\circ} 33^{\prime} \mathrm{S}$. Illumination is from the left.

Cerberus Fossae [e.g., Head et al., 2003; Manga, 2004]. Giant current ripples cannot yet be confidently identified at Mangala Valles, in part because candidate alluvial ripples cannot be clearly discriminated from aeolian landforms that can have similar appearances and dimensions (although highresolution photoclinometry and other techniques have potential in this regard [e.g., Burr et al., 2004]).

\section{Volcanic Processes as Alternative Mechanisms of Channel Formation at Mangala Valles}

[26] The aqueous-flood hypothesis for incision of the Mangala Valles channel system has been considered compelling on the basis of the strong and seemingly unique correspondence between the landforms of this system and those of terrestrial drainage systems such as the Channeled Scabland. The aqueous-flood hypothesis can account for the basic nature of the Mangala Valles system, and has as a result been appropriately used as a foundation for recent studies of the system. However, the conspicuously volcanotectonic nature of the Mangala Valles system, and shared morphological and contextual characteristics with large and apparently volcanic channels of the Moon and Venus, suggest that an alternative volcanic mechanism of formation should be developed for Mangala Valles, for consideration alongside the aqueous-flood mechanism.

[27] Formation of the Mangala Valles system was linked to igneous and tectonic processes. The system heads at a graben interpreted to have formed in association with Tharsis-related dike emplacement [e.g., Tanaka and Chapman, 1990; Mège et al., 2003; Schultz et al., 2004] and identified as a source of past effusive volcanic flows [e.g., Craddock and Greeley, 1994; Wilson and Head, 2002]. Landforms such as leveed subchannels (Figure 9; see also, e.g., THEMIS VIS V03676002), ridged plains (Figure 10; see also, e.g., THEMIS VIS V04425003), and segments of inverted channel topography (Figure 12) suggest that Mangala Valles channels acted as conduits and, at numerous locales along the channel system, depositional basins for past volcanic flows [e.g., Tanaka and Chapman, 1990; Chapman and Tanaka, 1993; Ghatan et al., 2005]. The presence at Mangala Valles of platy basin fill (Figure 14) and subchannels defined by collapse pits (Figure 15) further strengthen inferences that the channel system acted as a conduit for volcanic flows [e.g., see Greeley, 1971a, 1971b; Keszthelyi et al., 2000, 2004].

[28] The fluid that formed the Mangala Valles system must have incised its anastamosing channels (Figure 7) and carved or otherwise formed features such as the elongate landforms located in the lee of obstacles (Figure 6). The natural fluid to consider for formation of such features, on

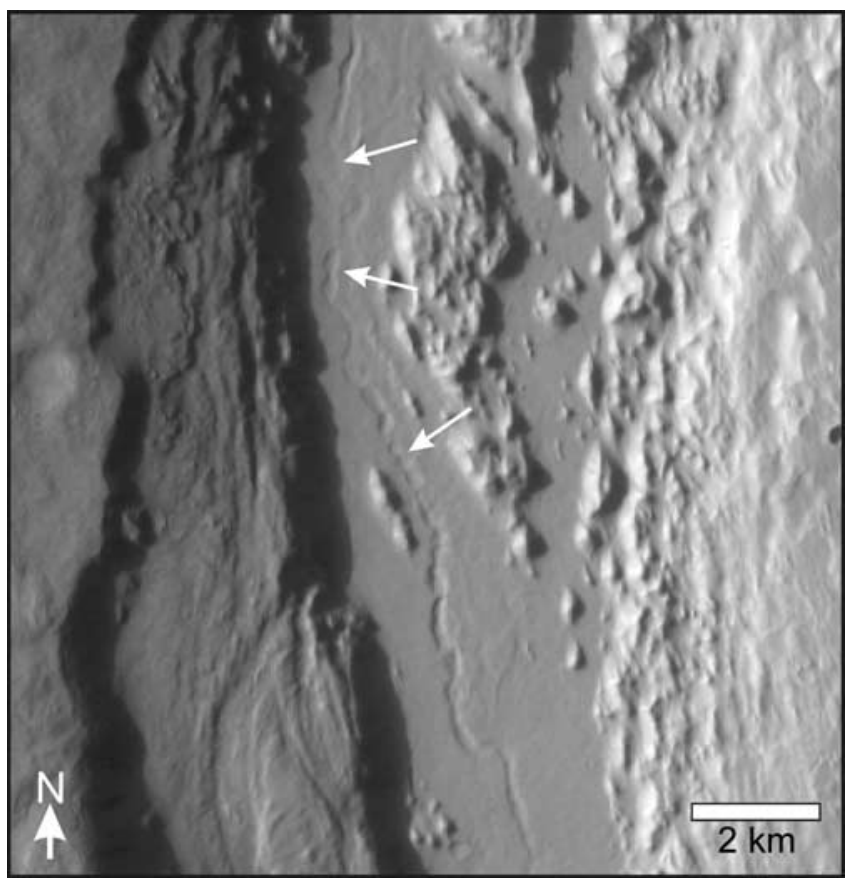

Figure 15. Mangala Valles subchannel that is discontinuously expressed at the surface. The basic nature of this channel appears to be consistent with that of roofed volcanic channels [e.g., Greeley, 1971a, 1971b]; other examples of such subchannels at Mangala Valles are visible in, e.g., MOC images M2100803 and R1003518. Band 3 of THEMIS VIS image V10716001. Figure center is at $\sim 150^{\circ} 00^{\prime} \mathrm{W}, 6^{\circ} 30^{\prime} \mathrm{S}$. Illumination is from the left. 


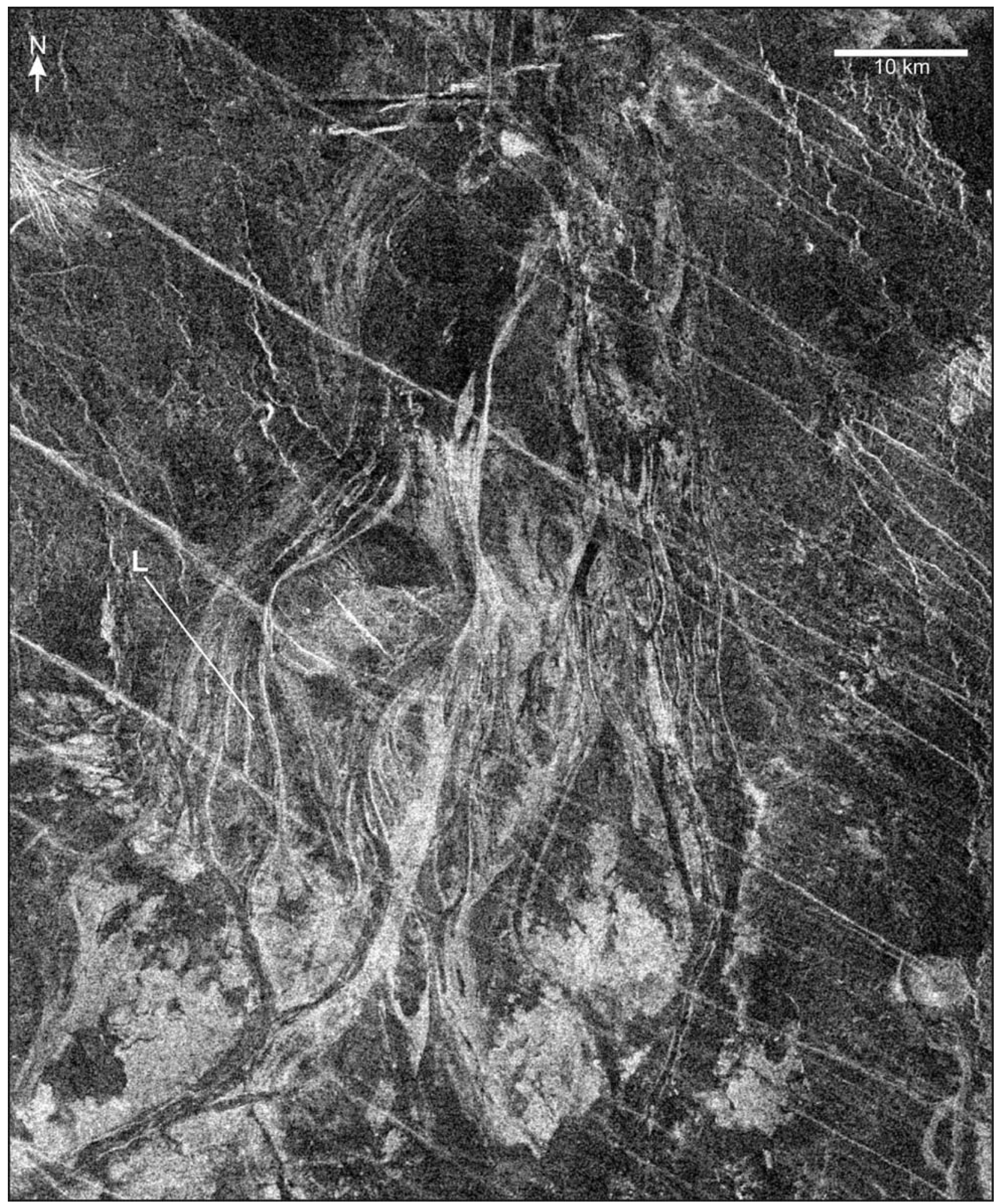

Figure 16. Magellan synthetic aperture radar image of a Venusian channel located northeast of Ozza Mons, eastern Aphrodite Terra. This channel, interpreted as volcanic, is characterized by complexly anastamosing reaches that define numerous streamlined islands that are kilometers to tens of kilometers across; these islands appear to be erosional residuals [Komatsu et al., 1993]. Some lineations in the radar imagery (e.g., L) could correspond to channel lineations, the banks of inner channels, or channel terraces. Flow along this reach was from south to north (figure bottom to top). Magellan FMAP left-look Synthetic Aperture Radar (SAR) mosaic; microwave illumination is from the left. Figure center is at $\sim 211^{\circ} 40^{\prime} \mathrm{E}$, $11^{\circ} 40^{\prime} \mathrm{N}$. 
the basis of terrestrial analogs, is water. However, although volcanic processes on the Earth are normally constructive in nature, theoretical and field-based studies have indicated that substantial amounts of incision and scour can result from the flow of molten rock through the processes of thermal and mechanical erosion (see discussion below). The possibility of formation of Martian outflow channels by the flow of lava has been suggested previously [Schonfeld, 1976, 1977, 1979; Cutts et al., 1978; Leverington, 2004; see also Carr, 1974b] and this possibility is consistent with the basic nature of large lunar and Venusian channels of apparent volcanic origin.

[29] Sinuous lunar rilles, formed volcanically [e.g., Greeley, 1971a, 1971b; Cruikshank and Wood, 1972; Hulme, 1973] in the absence of water [Keil et al., 1970; Schmitt et al., 1970; Papike et al., 1991], can have characteristics that match those of parts of the Mangala Valles system, including inner channels [e.g., El-Baz et al., 1972], channel levees [e.g., ElBaz and Roosa, 1972; Hulme, 1974; Schaber, 1973; Schultz, 1976], channel terraces [e.g., Schultz, 1976; Leverington, 2004; see also El-Baz et al., 1972], typical gradients of less than one degree [Strain and El-Baz, 1977], longitudinal profiles intermittently characterized by reverse gradients [e.g., Greeley, 1971a; Strain and El-Baz, 1977], and exposure of channel floors as a result of partial or complete drainage of late-stage lava pulses [e.g., Swann et al., 1972]. Rilles incised up to hundreds of meters into upland barriers across swaths as great as several kilometers exist on the Moon, with examples of incision located, e.g., at Rimae Herigonius [Greeley and Spudis, 1978; see also Young et al., 1973; Schultz, 1976; Leverington, 2006] and Rimae Prinz [Carr, 1974b; Schultz, 1976; Strain and El-Baz, 1977; Zisk et al., 1977; see also Masursky et al., 1978; Leverington, 2004]. Some lunar channels contain streamlined landforms that may be erosional residuals [Leverington, 2004, Figure 7].

[30] Venusian channels [e.g., Baker et al., 1992; Komatsu et al., 1992, 1993; Asimow and Wood, 1992; Chadwick and Schaber, 1993; Gregg and Greeley, 1993; Komatsu and Baker, 1994] can range from relatively simple sinuous landforms that have few or no tributaries and that have many of the basic characteristics of lunar sinuous rilles [Baker et al., 1992, 1997; Head et al., 1992; Komatsu and Baker, 1994] to complex channels with distinctly nonlunar characteristics such as complexly anastamosing reaches that define large streamlined "islands" [e.g., Baker et al., 1992]. Although alternative aqueous interpretations have been proposed [e.g., Jones and Pickering, 2003], the channels of Venus are generally believed to have formed by the flow of lava [e.g., Baker et al., 1992, 1997]. Evidence against aqueous origins includes the instability of liquid water under present conditions [e.g., Kargel et al., 1993], the absence of landforms suggestive of past precipitation and surface runoff, the correlation between channels and volcanic or impact-related sources [e.g., Asimow and Wood, 1992; Baker et al., 1997], and the apparent dry nature of the Venusian geological system [e.g., Donahue and Russell, 1997; Nimmo and McKenzie, 1998]. Geochemical data collected at seven Venera and Vega landing sites imply mafic compositions [e.g., Surkov, 1983; Surkov et al., 1987; Kargel et al., 1993], but no such data are available for Venusian channels; hypotheses for formation of channels by lavas of ultramafic or other compositions have been pro- posed to account for the apparent erosive properties of involved fluids [e.g., Baker et al., 1992].

[31] Large and complex Venusian channels include a prominent system located northeast of Ozza Mons (Figure 16) [Komatsu et al., 1993] and Kallistos Vallis, a 1200-km-long outflow channel at Astkhik Planum [e.g., Baker et al., 1992; see also Leverington, 2004, Figure 14]. Systems such as these share a wide range of characteristics with Mangala Valles, including channels that appear to have been incised into country rock, streamlined residual landforms, complexly anastamosing reaches, channels of variable width, exposure of channel floors through partial or complete drainage of latestage fluid flows, and channel lineations oriented along directions of paleoflow. The highest-resolution Magellan radar images have pixel dimensions of $\sim 100 \times 100 \mathrm{~m}$ (resampled to $\sim 75 \times 75 \mathrm{~m}$ for the full-resolution radar map, or FMAP, databases), rendering confident identification of bedforms (e.g., longitudinal grooves) on this spatial scale difficult. The coarseness of Magellan topographic databases of Venus, with resampled Global Topographic Data Record (GTDR) data characterized by pixel sizes of $\sim 5 \times 5 \mathrm{~km}$, severely inhibits meaningful quantification of the relief of channel bedforms and of channel depths. Magellan stereoimage data sets offer potential for generation of topographic databases of improved spatial resolution, but processing of these data sets can be challenging [e.g., Howington-Krause et al., 2006], and these data sets are not available for systems such as Kallistos Vallis. Importantly, although the attributes of numerous Venusian channels are suggestive of fluid erosion [e.g., Baker et al., 1992; Komatsu et al., 1993; Komatsu and Baker, 1994; Baker and Komatsu, 1999], the lack of high-resolution topographic data for Venus currently places limits on the confidence with which conclusions can be made in this regard.

[32] A volcanic interpretation of the Mangala Valles channel system is consistent with the basic properties and formation mechanisms of large volcanic channels of the inner solar system. This interpretation also appears to be consistent with the nature of Mangala Valles landforms previously interpreted as having formed through aqueous processes. The lobate-margined and festooned flow deposits proximal to the main source graben of Mangala Valles, previously interpreted as glacier-like landforms produced through phreatomagmatic processes and related outpourings of groundwater [Wilson and Head, 2004; Head et al., 2004], may alternatively be interpreted as ridged volcanic flows erupted from within the graben structure or channeled through the graben from Daedalia Planum. Such an interpretation is supported by the presence of similarly ridged and festooned volcanic flow units erupted from the same source graben at the volcanic plains of adjacent Daedalia Planum (Figure 17a), as well as at, e.g., the region east of the northern mouths of Mangala Valles (Figure 17b) (a volcanic interpretation is also consistent with the basic nature of volcanic deposits located elsewhere on Mars, Moon, and Earth [e.g., Mollard and Janes, 1984; Leverington and Maxwell, 2004; Greeley et al., 2005]). A volcanic interpretation is compatible with a wide range of climate conditions, whereas the predicted instability of surficial and near-surface water ice at latitudes within $\sim 30^{\circ}$ of the equator [e.g., Farmer and Doms, 1979] does not favor the presence of glaciers in this region. 

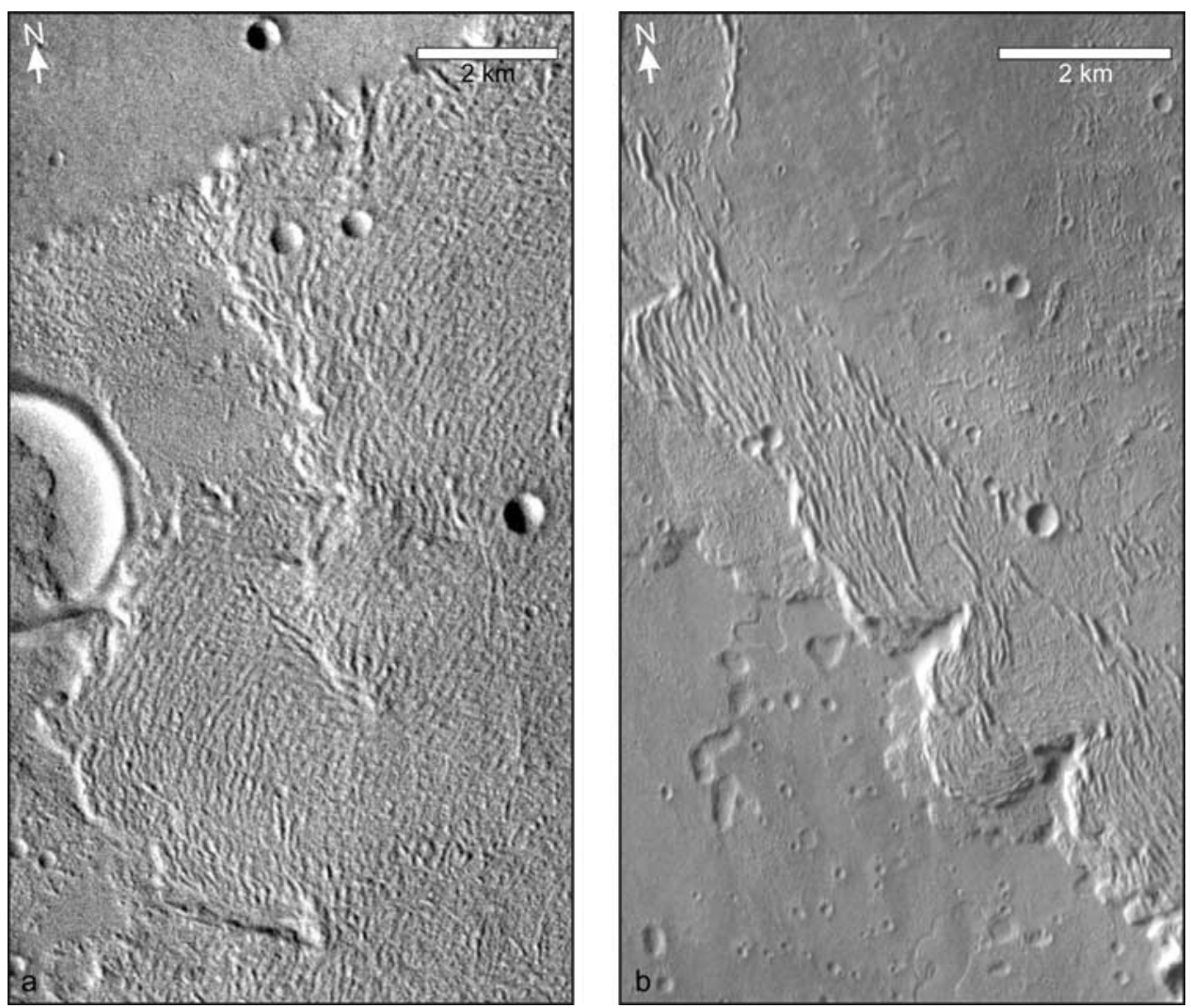

Figure 17. Ridged flows (a) at the source graben of Mangala Valles, east of the head of the channel system, and (b) near the mouths of the main channels of Mangala Valles. Compare with flows near the head of Mangala Valles (Figure 4). THEMIS VIS images (a) V15795005 (band 3) and (b) V11939001 (band 3). Figure centers are at (a) $\sim 146^{\circ} 00^{\prime} \mathrm{W}, 17^{\circ} 28^{\prime} \mathrm{S}$ and (b) $150^{\circ} 20^{\prime} \mathrm{W}, 4^{\circ} 04^{\prime} \mathrm{S}$. Illumination of both frames is from the left.

[33] Surface exposure of the deposits of the terminal basins of Mangala Valles is poor due to cover by materials of the Medusae Fossae Formation [e.g., Scott and Tanaka, 1986; Bradley et al., 2002; Hynek et al., 2003], as well as by dune fields and wind-scoured cover (e.g., MOC image M0001747), but exposed units are discontinuously found along the dichotomy boundary (Figure 18) as well as north of the Medusae Fossae Formation [e.g., Scott and Tanaka, 1986]. Exposed terminal deposits characterized by quasicircular depressions and cuspate margins (Figure 18a and Figure 18c (top)), and similar deposits found within some channels of Mangala Valles (Figure 8), have previously been interpreted as degrading water-ice-rich flood deposits [Zimbelman et al., 1992; Levy and Head, 2005]. However, deposits with comparable features have been emplaced at volcanic plains located, e.g., at the source graben of the Mangala Valles system at Daedalia Planum (Figure 19a), within the Arsia Mons caldera (Figure 19c), and on the eastern flanks of Pavonis Mons (Figure 19d). Furthermore, parts of the same Mangala Valles terminal deposits have a ridged and platy nature (e.g., Figure 18c (bottom)) that is matched at nearby volcanic units of Daedalia Planum (e.g., Figure 19b). The pitted and cuspate-margined units near the mouths of Mangala Valles channels are overlain in places by ridged and lobate-margined flows derived from the east and of likely volcanic nature (Figure 17b), but the partly buried units do not show visible signs of thermal disturbance related either to the heat of flows during emplacement or to the upward shift in melting isotherm that might have been associated with the thickening of surface cover over ice-rich units. A volcanic origin for the cuspate and pitted deposits at Mangala Valles is considered consistent with (1) characterization by surface textures matched at volcanic plains in the region; (2) association of these materials with volcanic flows in a range of environments far removed from outflow channels; (3) a lack of response of materials to changes in thermal conditions related to burial by volcanic flows; and (4) the presence of these deposits at equatorial latitudes where water ice is unstable [e.g., Farmer and Doms, 1979]. A volcanic origin for a substantial volume of materials beyond the mouths of Mangala Valles is required of the volcanic hypothesis, since although many large volcanic channel systems on the Moon and Venus lack lava deltas at their mouths, extensive volcanic deposits are always present at the terminal basins of these systems [e.g., Leverington, 2004]. The characteristics of the units at the northern mouths of the Mangala Valles system appear to be consistent with this requirement, as is the ridged and lobatemargined nature of units exposed north of the Medusae Fossae Formation [e.g., Scott and Tanaka, 1986].

[34] Prominent inverted-channel features found in a segment of the northern Mangala Valles system (Figure 12) have characteristics consistent with those expected of lava flows [e.g., Chapman and Tanaka, 1993], but these resistant 

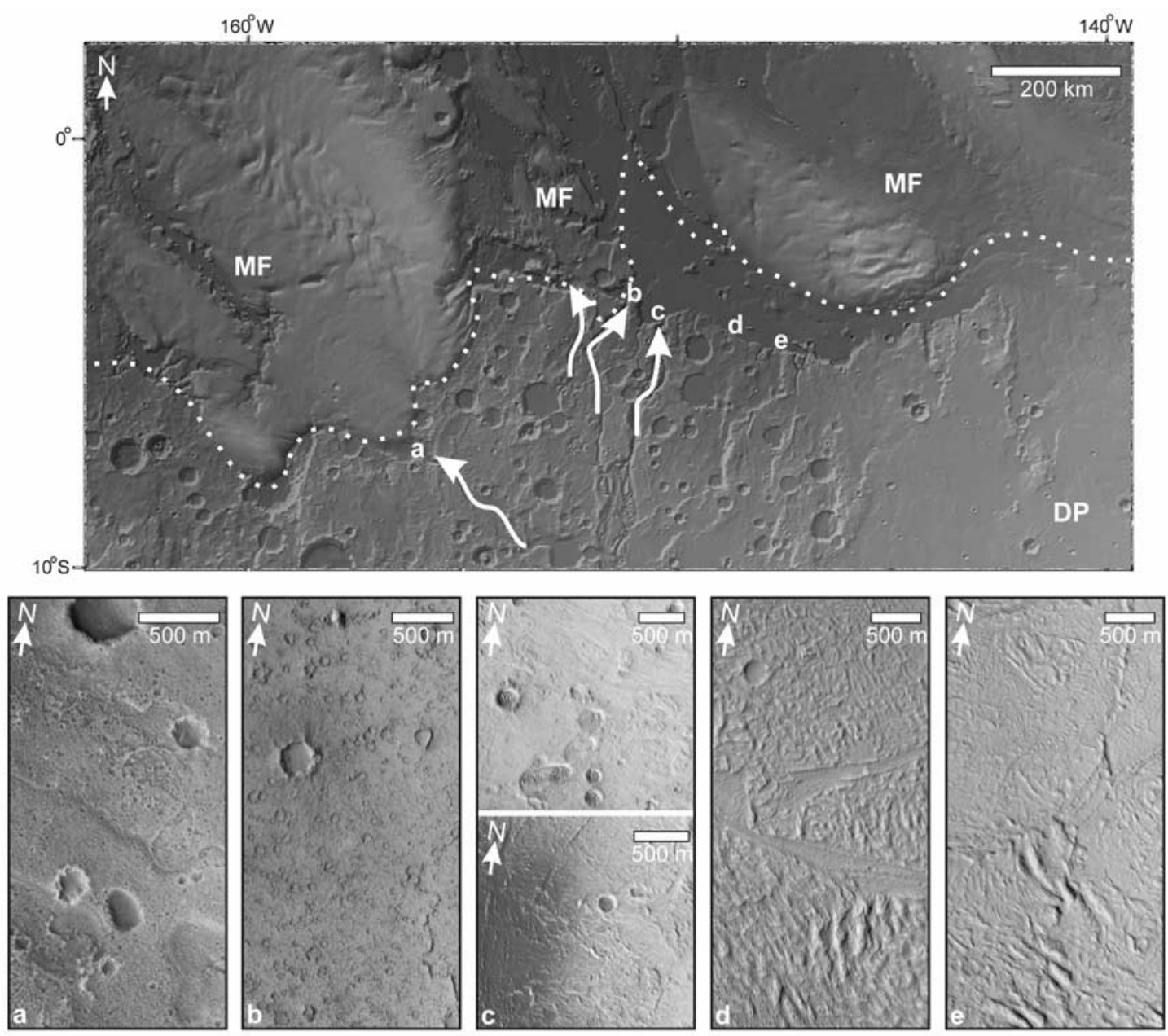

Figure 18. Surface deposits at and beyond the mouths of Mangala Valles. Although deposits of the terminal basin of the Mangala Valles system are extensively covered by the Medusae Fossae Formation (MF) and by a variety of aeolian and wind-scoured surface materials, exposed units (e.g., a-e) have characteristics consistent with volcanic plains such as those of nearby Daedalia Planum (DP) and the Tharsis rise (e.g., Figure 19); some exposed materials (e.g., d and e) appear to have flowed from the distal margins of western Arsia Mons and the Tharsis rise, a region that includes Daedalia Planum. Exposed units north of the Medusae Fossae Formation (north of the region depicted above) also have ridged and lobate-margined characteristics consistent with those expected of volcanic flows [e.g., Scott and Tanaka, 1986], but in this region are likely substantially derived from Olympus Mons. MOC images: (a) M0902753, (b) R1601419, (c) R0701371 (top and bottom), (d) R0101385, and (e) M0903883. Illumination of all frames is from the left. The map at top is based on shaded topography after Smith et al. [2003].

materials need not have been emplaced in a channel system carved by water. Many of the inverted features only partly fill the main Mangala Valles reaches within which they are nested (even accounting for subsequent erosional recession of channel rims), implying that host materials of the flows were channel-fill materials of relatively low resistance. The surface elevations of inverted channel-fill deposits generally match the elevations of corresponding rims of the main Mangala Valles channels, suggesting that host materials once filled the main channels here, rendering a diluvial origin for these host materials unlikely. Accumulation of ash or aeolian deposits would be consistent with the nature of infilling of these channel reaches, and is consistent with the once-greater sediment cover of the region implied by the abundance of aeolian deposits and yardang fields found across the region, extending south from the Medusae Fossae Formation. Other inverted channels in the region (e.g., features at the nearby volcanic plains of Daedalia Planum, V14859003, and a leveed channel in Noachian uplands adjacent to Mangala Valles, V16594001) also imply possible formation during confinement by now-eroded host materials of nonalluvial nature.

\section{Eruption Volumes and Effusion Rates}

[35] Observations of terrestrial lava flows suggest that the surface flow of mafic molten rock is non-Newtonian and is commonly laminar [e.g., Shaw et al., 1968; Shaw, 1969; Hulme, 1973, 1974, 1982; Carr, 1974b; Hulme and Fielder, 

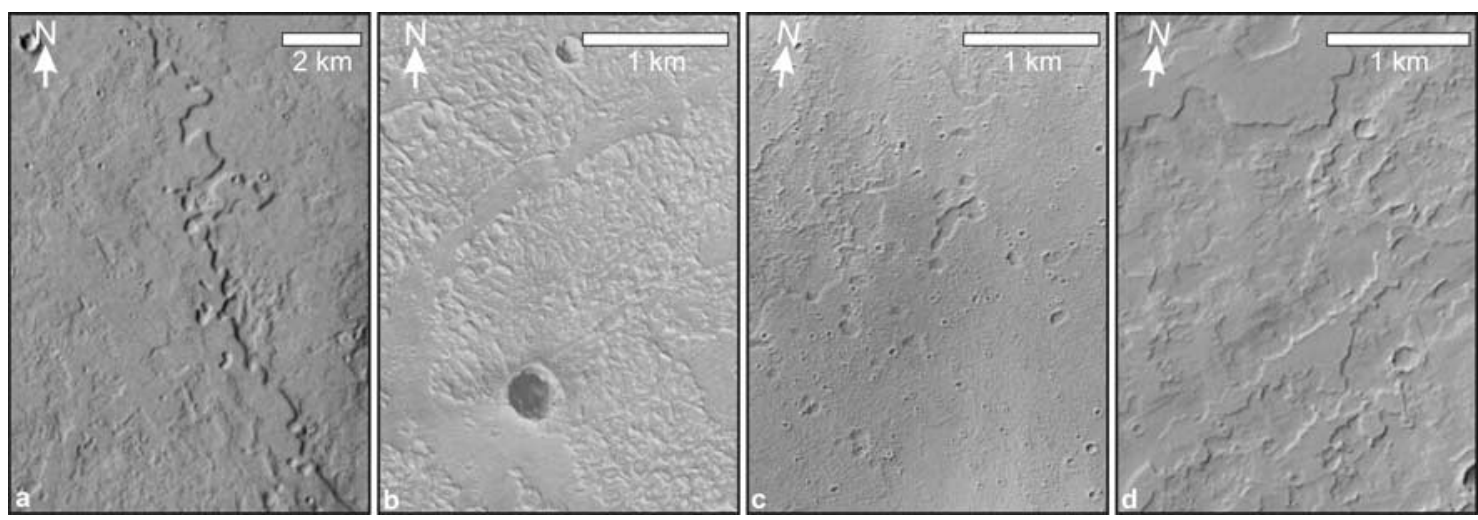

Figure 19. Examples of deposits at volcanic plains of the Tharsis region, including (a and b) Daedalia Planum, (c) the Arsia Mons caldera, and (d) the eastern flanks of Pavonis Mons. Images: (a) THEMIS VIS (band 3) V10566003; (b) MOC E1103781; (c) MOC E0301786; and (d) MOC M2000495. Figure centers are at (a) $\sim 145^{\circ} 25^{\prime} \mathrm{W}, 15^{\circ} 30^{\prime} \mathrm{S}$; (b) $\sim 144^{\circ} \mathrm{W}, 19^{\circ} 50^{\prime} \mathrm{S}$; (c) $\sim 120^{\circ} \mathrm{W}, 9^{\circ} 45^{\prime} \mathrm{S}$; and (d) $\sim 108^{\circ} 30^{\prime} \mathrm{W}$, $0^{\circ} 30^{\prime} \mathrm{S}$. Illumination of all frames is from the left.

1977; Wilson et al., 1982; Pinkerton and Wilson, 1994], although valid generalizations across planets and environmental conditions are elusive. For example, the yield strengths of lunar mare lavas may have been up to 100 times less than those of terrestrial basalts [Hulme, 1982], and high Reynolds numbers and associated turbulent behavior are expected to have characterized many large lunar and Martian basaltic flows erupted with low viscosities and very high effusion rates over mainly low topographic slopes [e.g., Hulme, 1973, 1982; Pinkerton et al., 1975; Hulme and Fielder, 1977; Wilson et al., 1982; Keszthelyi et al., 2006; see also Howard et al., 1972]. Despite a lack of full understanding of the nature of volcanic flow, theoretical and terrestrial field-based studies have indicated that substantial amounts of erosion can result from the flow of molten rock, with erosion by flowing lava likely taking place through the combined action of (1) thermal processes involving the melting of substrate materials by the heat of lava and (2) mechanical processes involving the physical removal of substrate materials by flowing lava [e.g., Hulme, 1973, 1982; Peterson and Swanson, 1974; Cutts et al., 1978; Barnes and Barnes, 1990; Greeley et al., 1998; Kauahikaua et al., 1998; Kerr, 2001; Wilson and Mouginis-Mark, 2001; Williams et al., 2004, 2005; Ferlito and Siewert, 2006]. As lava flows through a channel, heat is transferred through conduction and lava convection to the cooler underlying ground, and heat is also lost from the flow surface through convection and radiation [e.g., Hulme and Fielder, 1977; Flynn and Mouginis-Mark, 1994; Greeley et al., 1998; Harris and Rowland, 2001]. The loss of energy from the flow surface can result in formation of a fixed or free-floating insulating flow cover that can help maintain high lava temperatures over distances of hundreds or thousands of kilometers [e.g., Greeley, 1971a; Pinkerton et al., 1975; Wilhelms, 1987; Peterson et al., 1994; Sakimoto and Zuber, 1998], such that 20-30 m thick flows on Mars may be expected to cool by only $\sim 50-150 \mathrm{~K}$ after flow of $1500 \mathrm{~km}$ [Keszthelyi et al., 2006]. In thermal erosion, the channel substrate is heated until its temperature reaches its melting point, after which the substrate progressively undergoes phase change at constant temperature as latent heat is absorbed [e.g., Hulme, 1973, 1982; Hulme and Fielder, 1977; Kerr, 2001]. The temperature of liquids formed by phase change of substrate materials can be raised beyond melting temperatures through absorption of additional energy.

[36] Although erosion of an unconsolidated substrate might be accomplished by flowing lava without substantial phase change, erosion of solid bedrock could necessitate partial melting of up to $\sim 40 \%$ by weight [e.g., Hulme, 1973; see also, e.g., Greeley et al., 1998]. Field observations suggest that even small volcanic flows are capable of substantial erosion. For example, incision at an average rate of $10 \mathrm{~cm}$ per day over a period of two months has been measured at a small Hawaiian lava tube that developed near Pu'u 'O'o; this channel had width of only $4 \mathrm{~m}$, a flow velocity of $\sim 2.5 \mathrm{~m} / \mathrm{s}$, lava temperature of $\sim 1425 \mathrm{~K}$, and low Reynolds numbers of 16-64 that are indicative of laminar flow [Kauahikaua et al., 1998]. The capacity of lava for erosion of channel substrates is expected to be further enhanced by the presence of turbulent flow conditions [e.g., Hulme, 1973, 1982; Carr, 1974b; Pinkerton et al., 1975; Hulme and Fielder, 1977; Bussey et al., 1995; Greeley et al., 1998], the flow of lava over topographic irregularities that favor formation of lava falls [e.g., Kauahikaua et al., 1998; Kerr, 2001; Williams et al., 2004], the action of mechanical abrasion by lava and block fragments [e.g., Kauahikaua et al., 1998, 2002; Fagents and Greeley, 2001; Williams et al., 2004; Ferlito and Siewert, 2006], and heightened lava temperatures [e.g., Bussey et al., 1995]. Some of these factors are interrelated; for example, higher lava temperatures generally result in lower viscosities [e.g., Yan et al., 2001] which in turn can allow for greater flow turbulence [e.g., Hulme, 1982].

[37] Aspects of the nature of the flow of lava are yet to be fully described in a quantitative manner [e.g., MouginisMark et al., 1992; Fagents and Greeley, 2001] and a comprehensive theory of both thermal and mechanical erosion by lava has not yet emerged. The viability of volcanic mechanisms for formation of the Mangala Valles system is therefore, at present, best illustrated by the existence and geomorphological characteristics of large 


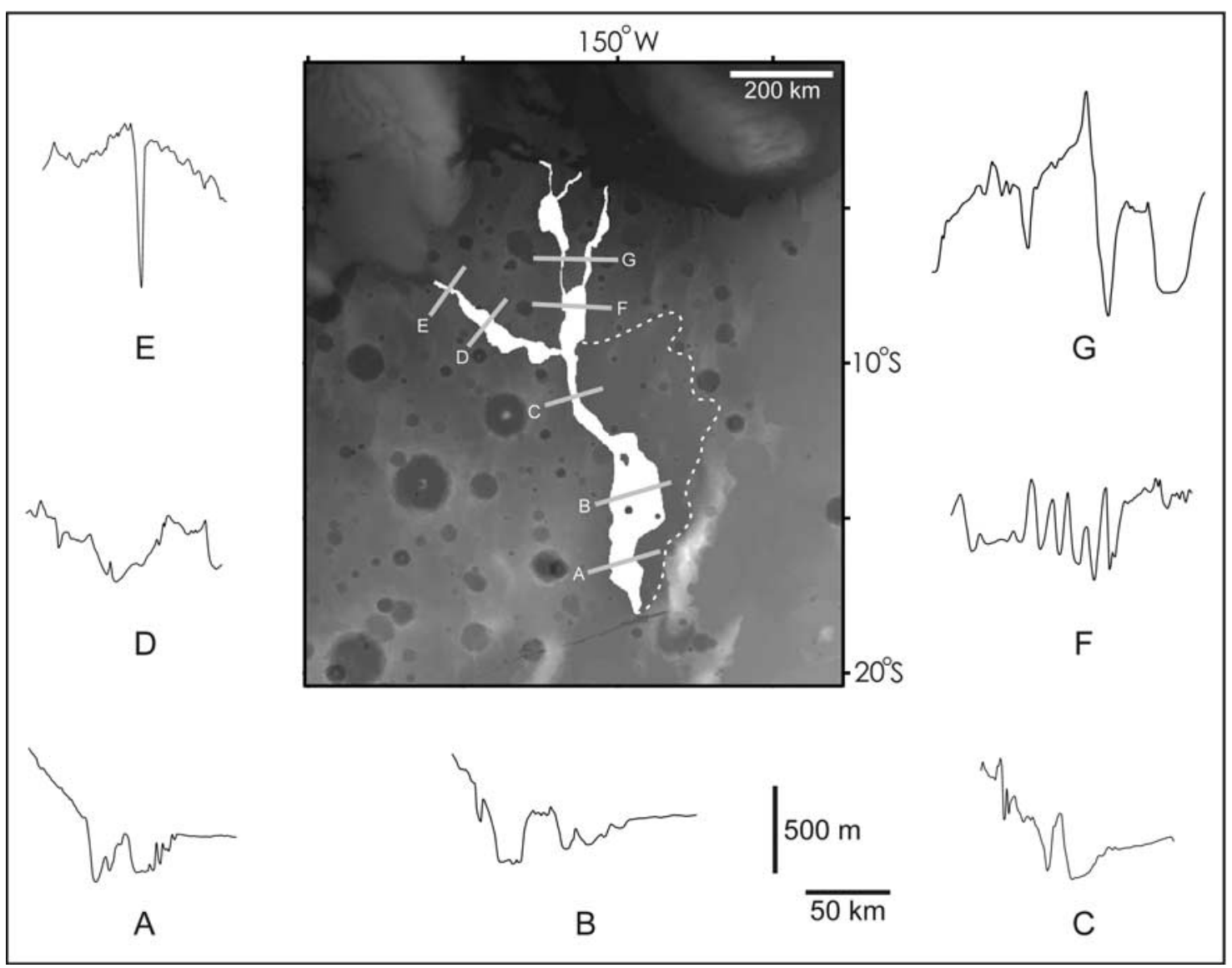

Figure 20. Mask of the main Mangala Valles system (white) overlain on MOLA topographic data (topographic model after Smith et al. [2003]) (see also Figure 1). Uniformly scaled topographic profiles along selected cross-channel transects are given (A to G). Extensive raised volcanic plains that appear to have formed in association with Mangala Valles are outlined by a dotted curve [see also Ghatan et al., 2005] but are not treated here as part of the main erosional channel system. The surface area of the main Mangala Valles system is $43,000 \mathrm{~km}^{2}$. Typical channel depths within this system range from $\sim 100$ to as much as $\sim 700 \mathrm{~m}$.

lunar and Venusian channels interpreted as volcanic [e.g., Greeley, 1971a, 1971b; Swann et al., 1972; Carr, 1974b; Strain and El-Baz, 1977; Wilhelms, 1987; Komatsu and Baker, 1994; Baker et al., 1992, 1997; Komatsu et al., 1993]. However, a crude estimate of the volume of lava that might have been involved in the hypothesized volcanic formation of Mangala Valles can be calculated on the basis of the minimum volume of material removed during channel formation. The main Mangala Valles system (Figure 20) has a total surface area of $43,000 \mathrm{~km}^{2}$. The form of the channel system is complex, with typical channel depths ranging from $\sim 100$ to as much as $\sim 700 \mathrm{~m}$ (Figure 20). Assuming a representative channel depth of $200 \mathrm{~m}$ (a depth of $100 \mathrm{~m}$ is assumed by Tanaka and Chapman [1990]), the minimum volume of material removed from the main Mangala Valles system is estimated to be about $8600 \mathrm{~km}^{3}$, a volume that is larger than the $3000 \mathrm{~km}^{3}$ estimate of Tanaka and Chapman [1990] and the $5700 \mathrm{~km}^{3}$ estimate implied by Hanna and Phillips [2006], but smaller than the 13,000-20,000 $\mathrm{km}^{3}$ estimate of Ghatan et al. [2005] (which also considers a region east of the main channels of Mangala Valles; see Figure 20). A volume greater than this $8600 \mathrm{~km}^{3}$ estimate could have been removed under the volcanic hypothesis for formation of Mangala Valles, on the basis of the tendency of lava to emplace solid fill materials within channel subbasins toward the terminations of individual eruption events, thus potentially leading to the removal of this additional material during subsequent flow events.

[38] For the purposes of order-of-magnitude estimations, the initial temperature of a magma of basaltic composition can be taken as 1450 K [e.g., Kauahikaua et al., 1998; Burgi et al., 2002] (although higher temperatures are possible), and initial cold-surface temperatures of Martian terrain can be taken as 220 K [e.g., Carr, 1996]. Substantial changes to the rheological properties of basaltic lava can take place at temperatures below $\sim 1400 \mathrm{~K}$ [e.g., Keszthelyi and Self, 1998], and thus the bulk temperature of basalt involved in hypothesized volcanic flows is not likely to have dropped substantially below this temperature during the main phases of hypothesized channel incision. Making the simplifying assumption that the densities and specific heat capacities of the solid and liquid phases of basalt are equal, the ratio of the mass of cold regolith to the mass of lava that would allow lava temperatures to be maintained at 
$\sim 1400 \mathrm{~K}$ can be estimated on the basis of conservation of energy to be $\sim 0.04$. Assuming a minimum volume of removed material to be $8600 \mathrm{~km}^{3}$, this figure implies a minimum total channel-forming lava volume of $\sim 2 \times$ $10^{5} \mathrm{~km}^{3}$. This volume estimate accounts for that amount of lava required to raise regolith to and above melting temperatures exclusively through thermal mechanisms, and does not take into account the energy required for phase change of heated surface materials. Assuming a density of basalt of $3000 \mathrm{~kg} / \mathrm{m}^{3}$ [e.g., Hulme, 1973, 1982] and a latent heat of fusion for basalt of $3.3 \times 10^{5} \mathrm{~J} / \mathrm{kg}$ [Yoder, 1976], an additional $\sim 8.5 \times 10^{21} \mathrm{~J}$ would be required to melt the full $8600 \mathrm{~km}^{3}$ of basalt bedrock at the melting temperature of $\sim 1275 \mathrm{~K}$. Assuming a total erupted lava volume of $2 \times 10^{5} \mathrm{~km}^{3}$ and a specific heat of mafic lava of $1200 \mathrm{~J} / \mathrm{kg} \mathrm{K}$, this value represents an additional drop in melt temperature of $\sim 11.8 \mathrm{~K}$ and thus, as expected [e.g., Hulme, 1982], is a relatively minor influence on the simplified scenario given above. The loss of energy associated with this drop in temperature is ultimately returned to the system as these melted materials re-crystallize, and the crystallization of an additional $2 \times 10^{5} \mathrm{~km}^{3}$ of erupted basalt results in the release of an additional $\sim 2 \times$ $10^{23} \mathrm{~J}$ (energy sufficient to raise the temperature of this volume by $\sim 280 \mathrm{~K}$ ). The large influx of energy resulting from crystallization of erupted lava is only partly offset by expected cooling along the channel system (cooling of $\sim 0.1 \mathrm{~K} / \mathrm{km}$ [Keszthelyi et al., 2006] results in cooling of $100 \mathrm{~K}$ along a $1000 \mathrm{~km}$ system) and by expected cooling at flow fronts and the source vent (amounting to an approximate total of tens of K [e.g., Keszthelyi et al., 2006]). Note that the bulk density of removed regolith is unlikely to have been equal to that of nonvesicular basalt (vesicular or particulate basalt can have much lower densities that can approach $\sim 1500 \mathrm{~kg} / \mathrm{m}^{3}$ ) [e.g., Yan et al., 2001], and it is likely that less than $40 \%$ of consolidated regolith would have needed to have undergone a phase change for channel erosion to have taken place [e.g., Hulme, 1973], and thus the energy required to warm and melt regolith is likely overestimated above for the volume estimate of $8600 \mathrm{~km}^{3}$.

[39] The timing of an event of total volume $2 \times 10^{5} \mathrm{~km}^{3}$ is extremely difficult to meaningfully estimate. Assuming an incision rate of $4 \times 10^{-6} \mathrm{~m} / \mathrm{s}$ (previously estimated for a smaller lunar channel located in the Marius Hills [see Hulme, 1973]), a total event time of 580 days is predicted, implying an average eruption rate of $4 \times 10^{6} \mathrm{~m}^{3} / \mathrm{s}$ (a total event time of 2000 days is predicted if a rate of incision of $1.16 \times 10^{-6} \mathrm{~m} / \mathrm{s}$, measured at the small Hawaiian channel discussed above [Kauahikaua et al., 1998], is used). Adding to the substantial uncertainties involved in these estimates is the lack of consideration of such factors as (1) the action of mechanical processes of erosion [e.g., Kauahikaua et al., 1998, 2002; Ferlito and Siewert, 2006] and (2) the influence of expected high levels of flow turbulence [e.g., Howard et al., 1972] on thermal erosion.

[40] The above estimates suggest a total volume of erupted lava of $2 \times 10^{5} \mathrm{~km}^{3}$, an average eruption rate of $4 \times 10^{6} \mathrm{~m}^{3} / \mathrm{s}$, and a combined event duration of 580 days. These values are crudely derived minimums that could conceivably underestimate the nature of hypothesized volcanic events by multiple orders of magnitude (though these values may also overestimate aspects of volcanic events, should, e.g., erupted magma temperatures have been notably greater than $1450 \mathrm{~K}$, or should processes of mechanical erosion have been significant). Formation of the Mangala Valles system by graben-fed flows, or by Daedalia Planum flows channeled through a segment of the source graben, might be speculated to have taken place in concert with the latter stages of formation of Arsia Mons. Such a scenario could have involved episodic development of the system over geologically extended periods of time that are not reflected in the duration estimate.

[41] Though enormous relative to the volumes of large historical terrestrial volcanic eruptions (a volume of $\sim 15 \mathrm{~km}^{3}$ was erupted during the $1783-1784$ fissure eruption at Laki, Iceland [Thordarson and Self, 1993]), the estimated Mangala Valles eruption volume of $2 \times 10^{5} \mathrm{~km}^{3}$ roughly corresponds to the total volume of $1.7 \times 10^{5} \mathrm{~km}^{3}$ of the terrestrial Columbia River Basalt Group [Tolan et al., 1989]; the largest individual flows of the Columbia Plateau flood basalts had volumes that in some cases exceeded $1000 \mathrm{~km}^{3}$ [Reidel, 1998]. An estimated eruption volume at Mangala Valles of $2 \times 10^{5} \mathrm{~km}^{3}$ is equivalent to $\sim 3-8 \%$ of the total estimated volume of lunar mare basalts if average mare thicknesses are taken to be between 1.0 and $0.4 \mathrm{~km}$, respectively [DeHon, 1974; Wilhelms, 1984], and represents $\sim 13 \%$ of the volume of the main Arsia Mons edifice on Mars [Smith et al., 2001]. The terminal basins of the Mangala Valles system extend from Lucus Planum northward to Amazonis Plantitia and Arcadia Planitia. Exposed units in these regions have characteristics consistent with volcanic origins (see discussion above), and flow of $2 \times 10^{5} \mathrm{~km}^{3}$ of lava into this broad region would result in total deposit thicknesses averaging 50 to $400 \mathrm{~m}$ for surface areas of $4 \times$ $10^{6}$ to $5 \times 10^{5} \mathrm{~km}^{2}$, respectively.

[42] The source of Mangala Valles is a component of the Tharsis-radial graben system interpreted as having formed in response to plume-related dike intrusion, with individual dikes predicted to have widths of $\sim 0.4 \mathrm{~km}$, heights of $\sim 100 \mathrm{~km}$, and lengths of up to $3000 \mathrm{~km}$ [Wilson and Head, 2002]. A dike with these dimensions will have a volume of $\sim 1.2 \times 10^{5} \mathrm{~km}^{3}$, which is of the same order of magnitude as the magma volume estimated above; the graben at the head of the Mangala Valles system is $\sim 1500 \mathrm{~km}$ long, corresponding to an estimated dike volume of $\sim 6 \times 10^{4} \mathrm{~km}^{3}$.

[43] The estimated effusion rate of $4 \times 10^{6} \mathrm{~m}^{3} / \mathrm{s}$ is far greater than the tens of cubic meters per second typical of modern terrestrial eruptions involving a wide range of lava compositions [e.g., Hon et al., 1994; Calvari et al., 2002; Kauahikaua et al., 2002], as well as the rates of less than $400 \mathrm{~m}^{3} / \mathrm{s}$ estimated for large historical eruptions at the Hawaiian Islands [e.g., Rowland and Walker, 1990]. A maximum effusion rate of $\sim 8.7 \times 10^{3} \mathrm{~m}^{3} / \mathrm{s}$ has been estimated for the Laki fissure eruption of 1783-1784 [Thordarson and Self, 1993]. However, the geological record suggests that past high-effusion volcanic events have taken place on the Earth, with eruption rates of $\sim 1 \times 10^{4}$ to $1 \times 10^{6} \mathrm{~m}^{3} / \mathrm{s}$ regarded as possible for individual flows of the Columbia River Basalt Group [Reidel, 1998]. The largest known effusive eruption of modern times appears to have occurred on Jupiter's moon, Io, at Pillan Patera, where peak effusion rates associated with the 1997 eruption of $31 \mathrm{~km}^{3}$ of lava over a 100-day period are estimated to 
have exceeded $1 \times 10^{4} \mathrm{~m}^{3} / \mathrm{s}$ [e.g., Davies et al., 2006]. Extreme rates of lava effusion have been cited as necessary to account for the sizes of large basalt flows on the Moon, with a rate of $1.3 \times 10^{6} \mathrm{~m}^{3} / \mathrm{s}$ estimated for emplacement of a single 400-km-long flow erupted from a fissure vent at Mare Imbrium [Schaber, 1973; Schaber et al., 1976]. Extrapolation of terrestrial and lunar effusion estimates suggests that rates up to and perhaps in excess of $1 \times 10^{6} \mathrm{~m}^{3} / \mathrm{s}$ should be associated with formation of flows with lengths of many hundreds of kilometers [Walker, 1973; Schaber et al., 1976]. Consistent with this perspective, rates of effusion equal to or exceeding $1 \times 10^{6} \mathrm{~m}^{3} / \mathrm{s}$ have been estimated for some Martian lava flows [Baloga and Pieri, 1986; Cattermole, 1987; Keszthelyi et al., 2006] and rates of up to $\sim 1 \times 10^{8} \mathrm{~m}^{3} / \mathrm{s}$ have been estimated for large individual volcanic flows on both the Moon and Mars [Zimbelman, 1998]. Rates of lava discharge of between $1 \times 10^{5}$ and $1 \times 10^{6} \mathrm{~m}^{3} / \mathrm{s}$ have been estimated for large flow fields on Venus [e.g., Lancaster et al., 1995], and a rate of up to $5 \times 10^{7} \mathrm{~m}^{3} / \mathrm{s}$ has been estimated for formation of Venusian outflow channel Kallistos Vallis [Baker et al., 1997].

\section{Discussion}

[44] Formation of the Mangala Valles system by catastrophic aqueous floods is consistent with similarities in the nature of landforms of this system and those of systems including the Channeled Scabland. However, a volcanic interpretation of the Mangala Valles system represents a viable (but unproven) alternative hypothesis on the basis of (1) the location of the head of the system at a large structural feature known to have acted as a source for effusive volcanic eruptions; (2) the distribution of landforms with volcanic affinities along and beyond the Mangala Valles system, suggesting past conveyance and pooling of large volcanic flows by the system; and (3) the potential for lunar and Venusian landforms to act as both morphological and process-based analogs for formation and evolution of the system. Indeed, the large lunar and Venusian channels developed through voluminous discharge from the subsurface, and, on this basis alone, might be argued to be more complete analogs to Mangala Valles than terrestrial systems formed in association with ice-dammed lakes. Rudimentary estimates of lava volume and effusion rates associated with hypothesized mechanisms of formation of Mangala Valles are consistent with those made previously for large volcanic landforms of the solar system.

[45] The volcanic hypothesis for formation of the Mangala Valles channel system is not encumbered by present or past instability of liquid water at the surface of Mars, whereas this issue has the potential to limit the viability of some aqueous scenarios [e.g., see Carr, 1996; Hoffman, 2000]. For example, the mechanism of near-surface dike emplacement for release of water from a cryosphere-confined aquifer could require periods of water release that are on the order of several million years [McKenzie and Nimmo, 1999], lengths of time that are not consistent with stability considerations for low latitudes [e.g., Farmer and Doms, 1979; Rossbacher and Judson, 1981; Clifford and Hillel, 1983], nor with the absence of large basins that could have acted as long-term surface reservoirs for later catastrophic floods. Uncertainty remains regarding the manner in which vast aquifers could have accumulated in the southern highlands of Mars, perched several kilometers above the floor of the northern lowlands in highly permeable and regionally interconnected regolith units [see, e.g., Clifford and Parker, 2001]. Deliberation also continues regarding the capacity of such aquifers to have catastrophically supplied massive volumes of water to the surface at rates required for aqueous outflow-channel formation [e.g., Head et al., 2003; Manga, 2004].

[46] The aqueous and volcanic hypotheses each represent end-members of a spectrum of possible processes that could have played key roles in the development of Mangala Valles, with the aqueous hypothesis involving simple volcanic resurfacing of a channel system otherwise formed primarily by catastrophic aqueous flows, and with the volcanic hypothesis involving channel formation by lava flow. A hybrid hypothesis would involve formation of the Mangala Valles channels through incision by aqueous flows, followed by or in concert with substantial modification of the system through erosion by volcanic flows. Other processes (e.g., glacial or $\mathrm{CO}_{2}$-related) cannot be dismissed out of hand, either as end-member hypotheses or as processes of secondary importance in channel evolution. Certainly, aeolian and mass-wasting processes have greatly influenced the landscape of the Mangala Valles region since the time of channel formation.

[47] A volcanic interpretation of Mangala Valles relies upon assumptions that (1) present volcanic interpretations of large lunar and Venusian channels are correct and (2) similarities in the characteristics of Martian, lunar, and Venusian channels reflect similarities regarding processes of formation. It is possible that neither assumption is valid. Progress regarding assessment of the end-member volcanic hypothesis should follow both from continued investigation of Mangala Valles and from further numerical modeling of large volcanic channel systems; aspects of such modeling efforts would be facilitated by acquisition of high-resolution topographic data sets for the Moon and Venus. Importantly, the end-member volcanic hypothesis discussed in this paper is testable. For example, identification of an aggradational origin (involving alluvial or diluvial processes) for large streamlined islands of the system would validate these features as true braid bars rather than simple erosional residuals, and would negate the end-member volcanic hypothesis for formation of Mangala Valles.

\section{Conclusions}

[48] Similarities in the nature of the channel landforms of Mangala Valles and those of aqueous flood systems have suggested possible commonalities in mechanisms of channel formation. However, a volcanic origin for the Mangala Valles system also appears viable on the basis of the following factors: (1) the system heads at a structural feature that acted as a source of past effusive volcanic eruptions; (2) the nature of surface materials at Mangala Valles is suggestive of past flow of large volumes of lava through the channel system to its terminal basins; and (3) large lunar and Venusian channel systems have the potential to act as both morphological and process-based analogs for formation and evolution of the system. Crude estimates suggest that formation of the channel system through thermal mech- 
anisms of lava incision could have taken place through eruption of $\sim 2 \times 10^{5} \mathrm{~km}^{3}$ of lava, a volume that under some conditions would involve an average eruption rate of $\sim 4 \times 10^{6} \mathrm{~m}^{3} / \mathrm{s}$ over a total event duration of almost 600 days (though likely taking place through multiple events over geological timescales). A smaller volume of lava would be required if mechanical processes of erosion were also substantially involved. The volcanic hypothesis for formation of Mangala Valles, and a hybrid hypothesis involving formation of Mangala Valles through aqueous processes followed by or in concert with substantial modification of the system by volcanic erosion and deposition, appears worthy of future consideration.

[49] Acknowledgments. The helpful reviews of Laszlo Keszthelyi, Devon Burr, and an anonymous reader are appreciated. The author acknowledges the use of Mars Orbiter Camera images processed by Malin Space Science Systems and Thermal Emission Imaging System images processed by Arizona State University.

\section{References}

Asimow, P. D., and J. A. Wood (1992), Fluid outflows from Venus impact craters: Analysis from Magellan data, J. Geophys. Res., 97(E8), 13,64313,665 .

Baker, V. R. (1973), Paleohydrology and Sedimentology of Lake Missoula Flooding in Eastern Washington, Spec. Pap. Geol. Soc. Am., vol. 144, Geol. Soc. of Am., Boulder, Colo.

Baker, V. R. (1978a), A preliminary assessment of the fluid erosional processes that shaped the Martian outflow channels, Proc. Lunar Planet Sci. Conf. 9th, 3205-3223.

Baker, V. R. (1978b), Large-scale erosional and depositional features of the Channeled Scabland, in The Channeled Scabland, edited by V. R. Baker and D. Nummedal, pp. 81-115, NASA Planet. Geol. Program, Washington, D. C.

Baker, V. R. (1978c), The Spokane flood controversy and the Martian outflow channels, Science, 202, 1249-1256.

Baker, V. R. (1982), The Channels of Mars, Univ. of Tex. Press, Austin.

Baker, V. R., and R. C. Bunker (1985), Cataclysmic late Pleistocene flooding from glacial Lake Missoula: A review, Quat. Sci. Rev., 4, 1-41.

Baker, V. R., and R. C. Kochel (1978a), Morphometry of streamlined forms in terrestrial and Martian channels, Proc. Lunar Planet Sci. Conf. 9th, 3193-3203

Baker, V. R., and R. C. Kochel (1978b), Morphological mapping of Martian outflow channels, Proc. Lunar Planet Sci. Conf. 9th, 3181-3192.

Baker, V. R., and R. C. Kochel (1979), Martian channel morphometry: Maja and Kasei Valles, J. Geophys. Res., 84, 7961-7983.

Baker, V. R., and G. Komatsu (1999), Extraterrestrial fluvial forms, in Varieties of Fluvial Form, edited by A. J. Miller and A. Gupta, pp. 11-30, John Wiley, Hoboken, N. J.

Baker, V. R., and D. J. Milton (1974), Erosion by catastrophic floods on Mars and Earth, Icarus, 23, 27-41.

Baker, V. R., G. Komatsu, T. J. Parker, V. C. Gulick, J. S. Kargel, and J. S. Lewis (1992), Channels and valleys on Venus: Preliminary analysis of Magellan data, J. Geophys. Res., 97(E8), 13,421-13,444.

Baker, V. R., G. Komatsu, V. C. Gulick, and T. J. Parker (1997), Channels and valleys, in Venus II, edited by S. W. Bougher, D. M. Hunten, and R. J. Phillips, pp. 757-793, Univ. of Ariz. Press, Tucson.

Baloga, S., and D. Pieri (1986), Time-dependent profiles of lava flows, J. Geophys. Res., 91, 9543-9552.

Barnes, S. J., and S.-J. Barnes (1990), A re-interpretation of the Katiniq nickel deposit, Ungava, northern Quebec, Econ. Geol., 85, 1269-1272.

Benito, G., and J. E. O'Connor (2003), Number and size of last-glacial Missoula floods in the Columbia River valley between the Pasco Basin, Washington, and Portland, Oregon, Bull. Geol. Soc. Am., 115, 624-638.

Boynton, W. V., et al. (2002), Distribution of hydrogen in the near surface of Mars: Evidence for subsurface ice deposits, Science, 297, 81-85.

Bradley, B. A., S. E. H. Sakimoto, H. Frey, and J. R. Zimbelman (2002), Medusae Fossae Formation: New perspectives from Mars Global Surveyor, J. Geophys. Res., 107(E8), 5058, doi:10.1029/2001JE001537.

Bretz, J. H. (1923), The channeled scablands of the Columbia Plateau, Geology, 31, 617-649.

Bretz, J. H. (1925), The Spokane flood beyond the Channeled Scabland, J. Geol., 33, 97-115, 236-259.

Bretz, J. H. (1928), Bars of Channeled Scabland, Bull. Geol. Soc. Am., 39, $643-702$.
Bretz, J. H., H. T. U. Smith, and G. E. Neff (1956), Channeled scabland of Washington: New data and interpretations, Bull. Geol. Soc. Am., 67, 957-1049.

Burgi, P.-Y., M. Caillet, and S. Haefeli (2002), Field temperature measurements at Erta'Ale lava lake, Ethiopia, Bull. Volcanol., 64, 472-485.

Burr, D. (2005), Clustered streamlined forms in Athabasca Valles, Mars: Evidence for sediment deposition during floodwater ponding, Geomorphology, 69, 242-252.

Burr, D. M., P. A. Carling, R. A. Beyer, and N. Lancaster (2004), Floodformed dunes in Athabasca Valles, Mars: Morphology, modeling, and implications, Icarus, 171, 68-83.

Bussey, D. B. J., S.-A. Sorensen, and J. E. Guest (1995), Factors influencing the capability of lava to erode its substrate: Application to Venus, J. Geophys. Res., 100(E8), 16,941-16,948.

Calvari, S., M. Neri, and H. Pinkerton (2002), Effusion rate estimates during the 1999 summit eruption on Mount Etna, and growth of two distinct lava flow fields, J. Volcanol. Geotherm. Res., 119, 107-123.

Carr, M. H. (1974a), Tectonism and volcanism of the Tharsis region of Mars, J. Geophys. Res., 79, 3943-3949.

Carr, M. H. (1974b), The role of lava erosion in the formation of lunar rilles and Martian channels, Icarus, 22, 1-23.

Carr, M. H. (1979), Formation of Martian flood features by release of water from confined aquifers, J. Geophys. Res., 84, 2995-3007.

Carr, M. H. (1981), The Surface of Mars, Yale Univ. Press, New Haven, Conn.

Carr, M. H. (1996), Water on Mars, Oxford Univ. Press, New York.

Carr, M. H. and R. Greeley (1980), Volcanic Features of Hawaii: A Basis for Comparison With Mars, NASA Spec. Publ., NASA SP-420, Natl. Aeron. and Space Admin., Washington, D. C.

Cattermole, P. (1987), Sequence, rheological properties, and effusion rates of volcanic flows at Alba Patera, Mars, Proc. Lunar Planet. Sci. Conf. 17th, Part 2, J. Geophys. Res., 92, suppl., E553-E560.

Chadwick, D. J., and G. G. Schaber (1993), Impact crater outflows on Venus: Morphology and emplacement mechanisms, J. Geophys. Res., 98(E11), 20,891-20,902.

Chapman, M. G. and K. L. Tanaka (1993), Geologic map of the MTM 05152 and -10152 quadrangles, Mangala Valles region of Mars, scale 1:500,000, U.S. Geol. Surv. Misc. Invest. Ser., Map I-2294, sheets 1 and 2 .

Chapman, M. G., H. Masursky, and A. L. Dial Jr. (1989), Geologic maps of science study site 1A, East Mangala Valles, Mars, scale 1:500,000, U.S. Geol. Surv. Misc. Invest. Ser., Map I-1962.

Clifford, S. M., and D. Hillel (1983), The stability of ground ice in the equatorial region of Mars, J. Geophys. Res., 88(B3), 2456-2474.

Clifford, S. M., and T. J. Parker (2001), The evolution of the Martian hydrosphere: Implications for the fate of a primordial ocean and the current state of the northern plains, Icarus, 154, 40-79.

Craddock, R. A. and R. Greeley (1994), Geologic map of the MTM 20147 quadrangle, Mangala Valles region of Mars, scale 1:500,000, U.S. Geol. Surv. Misc. Invest. Ser., Map I-2310.

Cruikshank, D. P., and C. A. Wood (1972), Lunar rilles and Hawaiian volcanic features: Possible analogues, Moon, 3, 412-447.

Cutts, J. A., W. J. Roberts, and K. R. Blasius (1978), Martian channels formed by lava erosion (abstract), Proc. Lunar Planet. Sci. Conf. 9th, 209.

Davies, A., L. Keszthelyi, and L. Wilson (2006), The biggest eruption ever witnessed: The effusion profile of the Pillan (Io) 1997 eruption, and the implications for massive basaltic flow emplacement on Earth and Mars, Abstract 30.03 presented at 38th Annual Division for Planetary Sciences Meeting, Am. Astron. Soc., Pasadena, Calif.

DeHon, R. A. (1974), Thickness of the western Mare basalts, Proc. Lunar Planet. Sci. Conf. 10th, 2935-2955.

Donahue, T. M. and C. T. Russell (1997), The Venus atmosphere and ionosphere and their interaction with the solar wind: An overview, in Venus II, edited by S. W. Bougher, D. M. Hunten, and R. J. Phillips, pp. 3-31, Univ. of Ariz. Press, Tucson.

El-Baz, F., and S. A. Roosa (1972), Significant results from Apollo 14 lunar orbital photography, Proc. Lunar Sci. Conf. 3rd, 63-83.

El-Baz, F., A. M. Worden, and V. D. Brand (1972), Astronaut observations from lunar orbit and their geologic significance, Proc. Lunar Sci. Conf. $3 r d, 85-104$

Fagents, S. A., and R. Greeley (2001), Factors influencing lava-substrate heat transfer and implications for thermomechanical erosion, Bull. Volcanol., 62, 519-532.

Farmer, C. B., and P. E. Doms (1979), Global seasonal variation of water vapor on Mars and the implications for permafrost, J. Geophys. Res. 84(B6), 2881-2888.

Feldman, W. C., et al. (2003), $\mathrm{CO}_{2}$ frost cap thickness on Mars during northern winter and spring, J. Geophys. Res., 108(E9), 5103, doi:10.1029/2003JE002101. 
Ferlito, C., and J. Siewert (2006), Lava channel formation during the 2001 eruption on Mount Etna: Evidence for mechanical erosion, Phys. Rev. Lett., 96, 028501, doi:10.1103/PhysRevLett.96.028501.

Flynn, L. P., and P. J. Mouginis-Mark (1994), Temperature of an active lava channel from spectral measurements, Kilauea Volcano, Hawaii, Bull. Volcanol., 56, 297-301.

Ghatan, G. J., J. W. Head III, and L. Wilson (2005), Mangala Valles, Mars: Assessment of early stages of flooding and downstream flood evolution, Earth Moon Planets, 96, 1-57, doi:10.1007/s11038-005-9009-y.

Goldspiel, J. M., S. W. Squyres, and D. G. Jankowski (1993), Topography of small Martian valleys, Icarus, 105, 479-500.

Greeley, R. (1971a), Lava tubes and channels in the lunar Marius Hills, Moon, 3, 289-314.

Greeley, R. (1971b), Lunar Hadley Rille: Considerations of its origin, Science, 172, 722-725.

Greeley, R., and P. D. Spudis (1978), Mare volcanism in the Herigonius region of the Moon, Proc. Lunar Planet. Sci. Conf. 9th, 3333-3349.

Greeley, R., S. A. Fagents, R. S. Harris, S. D. Kadel, and D. A. Williams (1998), Erosion by flowing lava: Field evidence, J. Geophys. Res., 103(B11), 27,325-27,345.

Greeley, R., B. H. Foing, H. Y. McSween Jr., G. Neukum, P. Pinet, M. van Kan, S. C. Werner, D. A. Williams, and T. E. Zegers (2005), Fluid lava flows in Gusev crater, Mars, J. Geophys. Res., 110, E05008, doi:10.1029/ 2005JE002401.

Gregg, T. K. P., and R. Greeley (1993), Formation of canali: Considerations of lava types of their thermal behaviors, J. Geophys. Res., 98, 10,87310,882 .

Hanna, J. C., and R. J. Phillips (2006), Tectonic pressurization of aquifers in the formation of Mangala and Athabasca Valles, Mars, J. Geophys. Res., 111, E03003, doi:10.1029/2005JE002546.

Harris, A. J. L., and S. K. Rowland (2001), FLOWGO: A kinematic thermo-rheological model for lava flowing in a channel, Bull. Volcanol., 63, $20-44$.

Hartmann, W. K. (1974), Geological observations of Martian arroyos, J. Geophys. Res., 79(26), 3951-3957.

Head, J. W., and L. Wilson (2002), Mars: General environments and geological settings of magma/ $\mathrm{H}_{2} \mathrm{O}$ interactions, in Volcano-Ice Interaction on Earth and Mars, edited by J. L. Smellie and M. G. Chapman, Geol. Soc. Spec. Publ., 202, 27-58.

Head, J. W., L. S. Crumpler, J. C. Aubele, J. E. Guest, and R. S. Saunders (1992), Venus volcanism: Classification of volcanic features and structures, associations, and global distribution from Magellan data, J. Geophys. Res., 97, 16,055-16,067.

Head, J. W., L. Wilson, and K. L. Mitchell (2003), Generation of recent massive water floods at Cerberus Fossae, Mars by dike emplacement, cryospheric cracking, and confined aquifer groundwater release, Geophys. Res. Lett., 30(11), 1577, doi:10.1029/2003GL017135.

Head, J. W., III, D. R. Marchant, and G. J. Ghatan (2004), Glacial deposits on the rim of a Hesperian-Amazonian outflow channel source trough: Mangala Valles, Mars, Geophys. Res. Lett., 31, L10701, doi:10.1029/ 2004GL020294

Hoffman, N. (2000), White Mars: A new model for Mars' surface and atmosphere based on $\mathrm{CO}_{2}$, Icarus, 146, 326-342.

Hon, K., J. Kauahikaua, R. Denlinger, and K. Mackay (1994), Emplacement and inflation of pahoehoe sheet flows: Observations and measurements of active lava flows on Kilauea Volcano, Hawaii, Geol. Soc. Am. Bull., 106, 351-370.

Howard, A. D., J. M. Moore, and R. P. Irwin III (2005), An intense terminal epoch of widespread fluvial activity on early Mars: 1. Valley network incision and associated deposits, J. Geophys. Res., 110, E12S14, doi:10.1029/2005JE002459.

Howard, K. A., J. W. Head, and G. A. Swann (1972), Geology of Hadley Rille, Proc. Lunar Sci. Conf. 3rd, 1-14.

Howington-Krause, E., R. L. Kirk, D. Galuszka, and B. Redding (2006), USGS Magellan stereomapping of Venus, paper presented at European Planetary Science Congress, Europlanet, Berlin, 18-22 Sept.

Hulme, G. (1973), Turbulent lava flow and the formation of lunar sinuous rilles, Mod. Geol., 4, 107-117.

Hulme, G. (1974), The interpretation of lava flow morphology, Geophys. J. R. Astron. Soc., 39, 361-383.

Hulme, G. (1982), A review of lava flow processes related to the formation of lunar sinuous rilles, Geophys. Surv., 5, 245-279.

Hulme, G., and G. Fielder (1977), Effusion rates and rheology of lunar lavas, Philos. Trans. R. Soc. London, Ser. A, 285, 227-234.

Hynek, B. M., and R. J. Phillips (2003), New data reveal mature, integrated drainage systems on Mars indicative of past precipitation, Geology, 31(9), $757-760$.

Hynek, B. M., R. J. Phillips, and R. E. Arvidson (2003), Explosive volcanism in the Tharsis region: Global evidence in the Martian geologic record, J. Geophys. Res., 108(E9), 5111, doi:10.1029/2003JE002062.
Jones, A. P., and K. T. Pickering (2003), Evidence for aqueous fluid-sediment transport and erosional processes on Venus, J. Geol. Soc. London, 160, 319-327.

Kargel, J. S., G. Komatsu, V. R. Baker, and R. G. Strom (1993), The volcanology of Venera and VEGA landing sites and the geochemistry of Venus, Icarus, 103, 253-275.

Karlsson, H. R., R. N. Claton, E. K. Gibson, and T. K. Mayeda (1992), Water in SNC meteorites: Evidence for a Martian hydrosphere, Science, $255,1409-1411$.

Kauahikaua, J., K. V. Cashman, T. N. Mattox, C. C. Heliker, K. A. Hon, M. T. Mangan, and C. R. Thornber (1998), Observations of basaltic lava streams in tubes from Kilauea Volcano, island of Hawai'i, J. Geophys. Res., 103(B11), 27,303-27,323.

Kauahikaua, J., K. V. Cashman, D. A. Clague, D. Champion, and J. T. Hagstrum (2002), Emplacement of the most recent lava flows on Hual lai Volcano, Hawai'i, Bull. Volcanol., 64, 229-253.

Keil, K., M. Prinz, and T. E. Bunch (1970), Mineral chemistry of lunar samples, Science, 167, 597-599.

Kerr, R. C. (2001), Thermal erosion by laminar lava flows, J. Geophys. Res., 106(B11), 26,453-26,465.

Keszthelyi, L., and S. Self (1998), Some physical requirements for the emplacement of long basaltic lava flows, J. Geophys. Res., 103(B11), 27,447-27,464.

Keszthelyi, L., A. S. McEwen, and T. Thordarson (2000), Terrestrial analogs and thermal models for Martian flood lavas, J. Geophys. Res., 105(E6), 15,027-15,049.

Keszthelyi, L., T. Thordarson, A. McEwen, H. Haack, M.-N. Guilbaud, S. Self, and M. J. Rossi (2004), Icelandic analogs to Martian flood lavas, Geochem. Geophys. Geosyst., 5, Q11014, doi:10.1029/2004GC000758.

Keszthelyi, L., S. Self, and T. Thordarson (2006), Flood lavas on Earth, Io and Mars, J. Geol. Soc. London, 163, 253-264.

Kieffer, H. H., S. C. Chase Jr., T. Z. Martin, E. D. Miner, and F. D. Palluconi (1976), Martian north pole summer temperatures: Dirty water ice, Science, 194, 1341-1344.

Komar, P. D. (1980), Modes of sediment transport in channelized water flows with ramifications to the erosion of the Martian outflow channels, Icarus, 42, 317-329.

Komatsu, G., and V. R. Baker (1994), Meander properties of Venusian channels, Geology, 22, 67-70.

Komatsu, G., J. S. Kargel, and V. R. Baker (1992), Canali-type channels on Venus: Some genetic constraints, Geophys. Res. Lett., 19, 1415-1418.

Komatsu, G., V. R. Baker, V. C. Gulick, and T. J. Parker (1993), Venusian channels and valleys: Distribution and volcanological implications, Icarus, $102,1-25$.

Lancaster, M. G., J. E. Guest, and K. P. Magee (1995), Great lava flow fields on Venus, Icarus, 118, 69-86.

Leverington, D. W. (2004), Volcanic rilles, streamlined islands, and the origin of outflow channels on Mars, J. Geophys. Res., 109, E10011, doi:10.1029/2004JE002311

Leverington, D. W. (2006), Volcanic processes as alternative mechanisms of landform development at a candidate crater-lake site near Tyrrhena Patera, Mars, J. Geophys. Res., 111, E11002, doi:10.1029/2004JE002382.

Leverington, D. W., and T. A. Maxwell (2004), An igneous origin for features of a candidate crater-lake system in western Memnonia, Mars, J. Geophys. Res., 109, E06006, doi:10.1029/2004JE002237.

Levy, J. S., and J. W. Head (2005), Evidence for remnants of ancient ice-rich deposits: Mangala Valles outflow channel, Mars, Terra Nova, 17(6), 503-509.

Lucchitta, B. K. (2001), Antarctic ice streams and outflow channels on Mars, Geophys. Res. Lett., 28(3), 403-406.

Lucchitta, B. K., D. M. Anderson, and H. Shoji (1981), Did ice streams carve Martian outflow channels?, Nature, 290, 759-763.

Manga, M. (2004), Martian floods at Cerberus Fossae can be produced by groundwater discharge, Geophys. Res. Lett., 31, L02702, doi:10.1029/ 2003GL018958

Mars Channel Working Group (1983), Channels and valleys on Mars, Geol. Soc. Am. Bull., 94, 1035-1054.

Masursky, H., J. M. Boyce, A. L. Dial, G. G. Schaber, and M. E. Strobell (1977), Classification and time of formation of Martian channels based on Viking data, J. Geophys. Res., 82, 4016-4038.

Masursky, H., G. W. Colton, and F. El-Baz (Eds.) (1978), Apollo Over the Moon: A View From Orbit, NASA Spec. Publ., NASA SP-362, 184 pp., Natl. Aeron. and Space Admin., Washington, D. C.

McCauley, J. F., M. H. Carr, J. A. Cutts, W. K. Hartmann, H. Masursky, D. J. Milton, R. P. Sharp, and D. E. Wilhelms (1972), Preliminary Mariner 9 report on the geology of Mars, Icarus, 17, 289-327.

McKenzie, D., and F. Nimmo (1999), The generation of Martian floods by the melting of ground ice above dykes, Nature, 397, 231-233.

Mège, D., A. C. Cook, E. Garel, Y. Lagabrielle, and M. Cormier (2003), Volcanic rifting at Martian grabens, J. Geophys. Res., 108(E5), 5044 doi:10.1029/2002JE001852. 
Mellon, M. T., and R. J. Phillips (2001), Recent gullies on Mars and the source of liquid water, J. Geophys. Res., 106(E10), 23,165-23,179.

Milton, D. J. (1973), Water and processes of degradation in the Martian landscape, J. Geophys. Res., 78(20), 4037-4047.

Mollard, J. D., and J. R. Janes (1984), Airphoto Interpretation and the Canadian Landscape, Energy, Mines, and Resour. Canada, Quebec, Canada.

Moore, J. M., A. D. Howard, W. E. Dietrich, and P. M. Schenk (2003), Martian Layered Fluvial Deposits: Implications for Noachian Climate Scenarios, Geophys. Res. Lett., 30(24), 2292, doi:10.1029/ 2003GL019002.

Mouginis-Mark, P. J., L. Wilson, and M. T. Zuber (1992), The physical volcanology of Mars, in Mars, edited by H. H. Kieffer et al., pp. 424 452, Univ. of Ariz. Press, Tucson.

Mutch, T. A., and E. C. Morris (1979), Geologic map of the Memnonia quadrangle of Mars, U.S. Geol. Surv. Misc. Invest. Ser., Map I-1137.

Nimmo, F., and D. McKenzie (1998), Volcanism and tectonics on Venus, Annu. Rev. Earth Planet. Sci., 26, 23-51.

Papike, J., L. Taylor, and S. Simon (1991), Lunar minerals, in Lunar Sourcebook, edited by G. H. Heiken, D. T. Vaniman, and B. M. French, pp. 121-181, Cambridge Univ. Press, New York.

Patton, P. C., and V. E. Baker (1978), Origin of the Cheney-Palouse scabland tract, in The Channeled Scabland, edited by V. B. Baker and D. Nummedal, pp. 117-130, NASA Planet. Geol. Program, Washington, D. C.

Peterson, D. W., and D. A. Swanson (1974), Observed formation of lava tubes during 1970-1971 at Kilauea Volcano, Hawaii, Stud. Speleol., 2, $209-222$.

Peterson, D. W., R. T. Holcomb, R. I. Tilling, and R. L. Christiansen (1994), Development of lava tubes in the light of observations at Mauna Ulu, Kilauea Volcano, Hawaii, Bull. Volcanol., 56, 343-360.

Pinkerton, H., and L. Wilson (1994), Factors controlling the lengths of channel-fed lava flows, Bull. Volcanol., 56, 108-120.

Pinkerton, H., R. Todhunter, and R. Hulme (1975), Lava flows and flood lavas, in Volcanoes of the Earth, Moon, and Mars, pp. 22-41, St. Martin's, New York.

Plescia, J. B., and R. S. Saunders (1982), Tectonic history of the Tharsis region of Mars, J. Geophys. Res., 87, 9775-9791.

Reidel, S. P. (1998), Emplacement of Columbia River flood basalt, $J$ Geophys. Res., 103(B11), 27,393-27,410.

Rossbacher, L. A., and S. Judson (1981), Ground ice on Mars: Inventory, distribution, and resulting landforms, Icarus, 45, 39-59.

Rowland, S. K., and G. P. L. Walker (1990), Pahoehoe and aa in Hawaii: Volumetric flow rate controls the lava structure, Bull. Volcanol., 52, $615-$ 628.

Sakimoto, S. E. H., and M. T. Zuber (1998), Flow and convective cooling in lava tubes, J. Geophys. Res., 103(B11), 27,465-27,487.

Schaber, G. G. (1973), Lava flows in Mare Imbrium: Geologic evaluation from Apollo orbital photography, Proc. Lunar Sci. Conf. 4th, 73-92.

Schaber, G. G., J. M. Boyce, and H. J. Moore (1976), The scarcity of mappable flow lobes on the lunar maria: Unique morpyhology of the Imbrium flows, Proc. Lunar Sci. Conf. 7th, 2783-2800.

Schmitt, H. H., G. Lofgren, G. A. Swann, and G. Simmons (1970), The Apollo 11 samples: Introduction, in Proceedings of the Apollo 11 Lunar Science Conference, pp. 1-54, Am. Assoc. for the Adv. of Sci., Washington, D. C.

Schonfeld, E. (1976), On the origin of the Martian channels (abstract), Eos. Trans. $A G U, 57(12), 948$.

Schonfeld, E. (1977), Martian volcanism (abstract), Proc. Lunar Sci. Conf. 8 th, $843-845$

Schonfeld, E. (1979), Origin of Valles Marineris, Proc. Lunar Planet. Sci. Conf. 10th, 3031-3038.

Schultz, P. H. (1976), Moon Morphology, Univ. of Tex. Press, Austin.

Schultz, R. A., C. H. Okubo, C. L. Goudy, and S. J. Wilkins (2004), Igneous dikes on Mars revealed by Mars Orbiter Laser Altimeter topography, Geology, 32(10), 889-892.

Scott, D. H., and K. L. Tanaka (1986), Geologic map of the western equatorial region of Mars, scale 1:15,000,000, U.S. Geol. Surv. Misc. Invest. Ser, Map I-1802-A.

Scott, D. H., and J. R. Zimbelman (1995), Geologic map of Arsia Mons volcano, Mars, scale 1:1,000,000, U.S. Geol. Surv. Misc. Invest. Ser, Map $I-2480$

Sharp, R. P., and M. C. Malin (1975), Channels on Mars, Geol. Soc. Am. Bull., 86, 593-609.

Shaw, H. R. (1969), Rheology of basalt in the melting range, J. Petrol., 10, $510-535$.

Shaw, H. R., T. L. Wright, D. L. Peck, and R. Okamura (1968), The viscosity of basaltic magma: An analysis of field measurements, Makaopuhi lake, Hawaii, Am. J. Sci., 266, 225-264.
Smith, D. E., et al. (1999), The global topography of Mars and implications for surface evolution, Science, 284, 1495-1503.

Smith, D. E., et al. (2001), Mars Orbiter Laser Altimeter (MOLA): Experiment summary after the first year of global mapping of Mars, J. Geophys. Res., 106, 23,689-23,722.

Smith, D., G. Neumann, R. E. Arvidson, E. A. Guinness, and S. Slavney (2003), Mars Global Surveyor Laser Altimeter Mission Experiment Gridded Data Record, MGS-M-MOLA-5-MEGDR-L3-V1.0, NASA Planet. Data Syst., Washington, D. C

Smith, G. A. (1993), Missoula flood dynamics and magnitudes inferred from sedimentology of slack-water deposits on the Columbia Plateau, Washington, Geol. Soc. Am. Bull., 105, 77-100.

Strain, P. L., and F. El-Baz (1977), Topography of sinuous rilles in the Harbinger Mountains region of the Moon, Moon, 16, 221-229.

Surkov, Y. A. (1983), Studies of Venus rocks by Veneras 8, 9, and 10, in Venus, edited by D. M. Hunten et al., pp. 154-158, Univ. of Ariz. Press, Tucson.

Surkov, Y. A., F. F. Kirnozov, V. N. Glazov, A. G. Dunchenko, L. P. Tatsy, and O. P. Sobornov (1987), Uranium, thorium, and potassium in the Venusian rocks at the landing sites of Vega 1 and 2, Proc. Lunar Planet. Sci. Conf. 17, Part 2, J. Geophys. Res., 92, suppl., E537-E540.

Swann, G. A., et al. (1972), Preliminary geologic investigations of the Apollo 15 landing site, in Apollo 15 Preliminary Science Report, NASA Spec. Publ., NASA SP-289, pp. 5-1 to 5-112, Natl. Aeron. and Space Admin., Washington, D. C

Tanaka, K. L., and M. G. Chapman (1990), The relation of catastrophic flooding of Mangala Valles, Mars, to faulting of Memnonia Fossae and Tharsis volcanism, J. Geophys. Res., 95(B9), 14,315-14,323.

Thompson, D. E. (1979), Origin of longitudinal grooving in Tiu Valles, Mars: Isolation of responsible fluid types, Geophys. Res. Lett., 6, $735-$ 738 .

Thordarson, T., and S. Self (1993), The Laki (Skaftar Fires) and Grimsvotn eruptions, 1783-1785, Bull. Volcanol., 55, 233-263.

Tolan, T. L., S. P. Reidel, M. H. Beeson, J. L. Anderson, K. R. Fecht, and D. A. Swanson (1989), Revisions to the estimates of the areal extent and volume of the Columbia River Basalt Group, in Volcanism and Tectonism in the Columbia River Flood Basalt Province, edited by S. P. Reidel and P. R. Hooper, Spec. Pap. Geol. Soc. Am., 239, 1-20.

Treiman, A. H. (1985), Amphibole and hercynite spinel in Shergotty and Zagami: Magmatic water, depth of crystallization, and metasomatism, Meteoritics, 20, 229-243.

Walker, G. P. L. (1973), Lengths of lava flows, Philos. Trans. R. Soc. London, Ser. A, 274, 107-118.

Wilhelms, D. E. (1984), Moon, in The Geology of the Terrestrial Planets, edited by M. H. Carr, NASA Spec. Publ., NASA SP-469, 107-205.

Wilhelms, D. E. (1987), The Geologic History of the Moon, U.S. Geol. Surv. Prof. Pap., 1348.

Williams, D. A., S. D. Kadel, R. Greeley, C. M. Lesher, and M. A. Clynne (2004), Erosion by flowing lava: Geochemical evidence in the Cave Basalt, Mount St. Helens, Washington, Bull. Volcanol., 66, 168-181.

Williams, D. A., R. Greeley, E. Hauber, K. Gwinner, and G. Neukum (2005), Erosion by flowing Martian lava: New insights for Hecates Tholus from Mars Express and MER data, J. Geophys. Res., 110, E05006, doi:10.1029/2004JE002377.

Wilson, L., and J. W. Head III (2002), Tharsis-radial graben systems as the surface manifestation of plume-related dike intrusion complexes: Models and implications, J. Geophys. Res., 107(E8), 5057, doi:10.1029/ 2001JE001593.

Wilson, L., and J. W. Head III (2004), Evidence for a massive phreatomagmatic eruption in the initial stages of formation of the Mangala Valles outflow channel, Mars, Geophys. Res. Lett., 31, L15701, doi:10.1029/ 2004GL020322.

Wilson, L., and P. J. Mouginis-Mark (2001), Estimation of volcanic eruption conditions for a large flank event on Elysium Mons, Mars, J. Geophys. Res., 106(E9), 20,621-20,628.

Wilson, L., J. W. Head, and P. J. Mouginis-Mark (1982), Theoretical analysis of Martian volcanic eruption mechanisms, in The Planet Mars, Eur. Space Agency Spec. Publ., ESA-SP 185, 107-113.

Wilson, L., G. J. Ghatan, J. W. Head III, and K. L. Mitchell (2004), Mars outflow channels: A reappraisal of the estimation of water flow velocities from water depths, regional slopes, and channel floor properties, J. Geophys. Res., 109, E09003, doi:10.1029/2004JE002281.

Wise, D. U., M. P. Golombek, and G. E. McGill (1979), Tharsis province of Mars: Geologic sequence, geometry, and a deformation mechanism, Icarus, 38, 456-472.

Yan, Q. Y., H. P. Tan, and D. K. Shang (2001), Physical properties of basalt and numerical simulation of the melting process in basalt particle beds, Int. J. Thermophys., 22, 995-1015.

Yoder, H. S., Jr. (1976), Generation of Basaltic Magma, Natl. Acad. of Sci/, Washington, D. C. 
Young, R. A., W. J. Brennan, R. W. Wolfe, and D. J. Nichols (1973), Analysis of lunar mare geology from Apollo photography, Proc. Lunar Sci. Conf. 4th, 57-71.

Zimbelman, J. R. (1998), Emplacement of long lava flows on planetary surfaces, J. Geophys. Res., 103(B11), 27,503-27,516.

Zimbelman, J. R., R. A. Craddock, R. Greeley, and R. O. Kuzmin (1992), Volatile history of Mangala Valles, Mars, J. Geophys. Res., 97(E11), $18,309-18,317$.
Zimbelman, J. R., R. A. Craddock, and R. Greeley (1994), Geologic map of the MTM-15147 quadrangle, Mangala Valles region of Mars, scale 1:500,000, U.S. Geol. Surv. Misc. Invest. Ser., Map I-2402.

Zisk, S. H., C. A. Hodges, H. J. Moore, R. W. Shorthill, T. W. Thompson, E. A. Whitaker, and D. E. Wilhelms (1977), The Aristarchus-Harbinger region of the Moon: Surface geology and history from recent remote sensing observations, Moon, 17, 59-99.

D. W. Leverington, Department of Geosciences, Texas Tech University, Box 41053, Lubbock, TX 79409-1053, USA. (david.leverington@ttu.edu) 